\title{
Strategies for Deliberate Induction of Immune Tolerance in Liver Transplantation: From Preclinical Models to Clinical Application
}

\author{
Naoki Tanimine ${ }^{1}$, Masahiro Ohira ${ }^{1,2}$, Hiroyuki Tahara ${ }^{1}$, Kentaro Ide $^{1}$, Yuka Tanaka ${ }^{1}$, \\ Takashi Onoe ${ }^{1,3}$ and Hideki Ohdan ${ }^{1 *}$ \\ ${ }^{1}$ Department of Gastroenterological and Transplant Surgery, Graduate School of Biomedical and Health Sciences, Hiroshima \\ University, Hiroshima, Japan, ${ }^{2}$ Medical Center for Translational and Clinical Research Hiroshima University Hospital, \\ Hiroshima, Japan, ${ }^{3}$ Kure Medical Center and Chugoku Cancer Center, National Hospital Organization, Kure, Japan
}

OPEN ACCESS

Edited by:

Ye Htun Oo,

University of Birmingham,

United Kingdom

Reviewed by:

Guido Moll,

Charité - Universitätsmedizin

Berlin, Germany

Orestis Argyros,

GlaxoSmithKline, United Kingdom

${ }^{*}$ Correspondence:

Hideki Ohdan

hohdan@hiroshima-u.ac.jp

Specialty section:

This article was submitted to

Alloimmunity and Transplantation,

a section of the journal

Frontiers in Immunology

Received: 01 April 2020

Accepted: 17 June 2020

Published: 31 July 2020

Citation:

Tanimine N, Ohira M, Tahara H, Ide K, Tanaka Y, Onoe $T$ and Ohdan H (2020)

Strategies for Deliberate Induction of Immune Tolerance in Liver Transplantation: From Preclinical Models to Clinical Application.

Front. Immunol. 11:1615

doi: 10.3389/fimmu.2020.01615
The liver exhibits intrinsic immune regulatory properties that maintain tolerance to endogenous and exogenous antigens, and provide protection against pathogens. Such an immune privilege contributes to susceptibility to spontaneous acceptance despite major histocompatibility complex mismatch when transplanted in animal models. Furthermore, the presence of a liver allograft can suppress the rejection of other solid tissue/organ grafts from the same donor. Despite this immune privilege of the livers, to control the undesired alloimmune responses in humans, most liver transplant recipients require long-term treatment with immune-suppressive drugs that predispose to cardiometabolic side effects and renal insufficiency. Understanding the mechanism of liver transplant tolerance and crosstalk between a variety of hepatic immune cells, such as dendritic cells, Kupffer cells, liver sinusoidas endothelial cells, hepatic stellate cells and so on, and alloreactive T cells would lead to the development of strategies for deliberate induction of more specific immune tolerance in a clinical setting. In this review article, we focus on results derived from basic studies that have attempted to elucidate the immune modulatory mechanisms of liver constituent cells and clinical trials that induced immune tolerance after liver transplantation by utilizing the immune-privilege potential of the liver.

Keywords: tolerance, liver, transplantation, immunosuppression, immunomonitoring

\section{INTRODUCTION}

Liver transplantation is currently a highly successful treatment for end-stage liver disease. It is well-known that liver allografts are tolerogenic, and stable grafts can be maintained across major histocompatibility complex (MHC) barriers without immunosuppression (IS) in some species (1-3). Furthermore, the presence of a liver allograft can suppress the rejection of other solid tissue grafts (e.g., heart and skin) from the same donor; hence, the liver favors introduction of immune tolerance rather than immunity $(2,4)$. Such a capacity of the transplanted liver to establish tolerance in an allogeneic host has been ascribed to the unique features and anatomical structure of hepatic constituent cells. In a clinical setting, however, the majority of liver transplant (LT) recipients require long-term immunosuppressive drug treatment to control the alloimmune responses. The undesired adverse effects of life-long IS remain a concern, that is, an increased risk of chronic kidney disease, metabolic disorders, infection and malignancy in LT recipients. 
Safely minimizing or discontinuing IS without compromising liver allograft can be an attractive strategy to improve longterm survival after liver transplantation. For this purpose, significant efforts have been made to identify sensitive and specific biomarkers of immune tolerance in LT recipients or to establish reliable immune monitoring methods. Understanding the mechanism of the inherently tolerogenic nature of the liver would lead to the development of strategies for deliberate induction of more specific immune tolerance in clinical liver transplantation. Immune regulation in the liver is mainly controlled by a variety of antigen presenting cells (APCs), which spatiotemporally react with alloreactive $\mathrm{T}$ cells in LT recipients. In addition to professional APCs, such as dendritic cells (DCs), unique populations of non-professional APCs consisting of Kupffer cells, liver sinusoidal endothelial cells (LSECs), and hepatic stellate cells (HSCs) that express low levels of MHC class I/II and co-stimulatory molecules are resident in a steady-state liver. These cells are likely involved in fine-tuning the modulation of local and systemic tolerance and/or immunity after liver transplantation. In this review article, we focus on studies that attempted to elucidate the immune modulatory mechanisms of these APCs, and clinical trials that induced immune tolerance after liver transplantation by enjoying the immune-privilege potential of the liver.

\section{ROLE OF APCS IN IMMUNE TOLERANCE IN LIVER TRANSPLANTATION}

\section{Dendritic Cells}

In mice, liver, but not other organ allografts, are accepted permanently and with donor specificity between many strain combinations, without the requirement for IS (3). It has been demonstrated that donor-derived DC precursors of liver allografts can be propagated in granulocyte macrophage colonystimulating factor (GMC-SF) from the bone marrow (BM) or spleen of unmodified LT recipients in mouse model, suggesting that bidirectional leukocyte migration and donor cell chimerism contribute to liver graft acceptance and acquired transplantation tolerance (5). A recent study supported the assumption that DCs contribute to tolerance by demonstrating that recipients of DC-depleted liver allograft showed acute rejection while those receiving non-manipulated liver allograft showed indefinite acceptance in a transgenic mouse model (6). It has been previously shown that Flt3 ligand administration, which increases interstitial DCs and their interleukin (IL)12 production, abrogated the acceptance of transplanted liver, and IL-12 neutralization markedly prolonged graft survival in mice receiving the Flt3 ligand $(7,8)$. In addition, it has been reported that the transmembrane adaptor protein, DNAXactivating protein of $12 \mathrm{kDa}$ (DAP12), negatively regulates liver myeloid DC maturation and stimulation ability, and $D A P 12^{-/-}$livers are rejected in relation to increased proinflammatory cytokines including IL-12p40 (9). These results suggest that DAP12 expression by liver DCs may be critical for the induction of tolerance. Hence, donor-derived DCs assuredly contribute to tolerance status; however, it likely depends on the DC subset and inflammatory status after transplantation. Recently, it has been reported that DCs contribute to tolerance in another mechanism in context of regulatory $\mathrm{T}$ cells (Tregs) IS, i.e., antigen (Ag)-specific Tregs that are formed strong interactions with DCs, result in the removal of the $\mathrm{Ag}$ and $\mathrm{MHC}$ class II complex from DC surface and reducing DC's Ag-presenting capacity (10). This might be one mechanism of tolerance induction by DCs. Based on such knowledge obtained in the preclinical_models, clinical trial for operational tolerance using regulatory DCs has been conducted (11). As a result, it has been shown that infusion of donor-derived, ex-vivo generated regulatory DCs can achieve operational tolerance in patients after liver transplantation, encouraging tolerance induction strategy with regulatory DCs in the future.

\section{Liver Sinusoidal Endothelial Cells}

The sinusoids correspond to the capillaries of the liver, and have a more complex structure than ordinary capillaries. The diameter of the sinusoids is $5-7 \mu \mathrm{m}$, which is narrow enough to allow circulating lymphocytes to contact LSECs closely with effective immune interaction. In fact, LSECs constitutively express the molecules necessary for Ag presentation (CD80, CD86, CD40, and MHC classes I and II), and have the capacity for Ag presentation, which is not observed in endothelial cells of other organs (12). Furthermore, LSECs express Fasligand and programmed death-ligand (PD-L) 1, which has been recently attracted due to Nobel-prize winning checkpoint inhibitor studies (13-15). These molecules on LSECs induce apoptosis of reactive $\mathrm{T}$ cells, and suppress allo-reactive and Ag-specific $\mathrm{T}$ cells in a mouse model $(12,16-18)$. LSECs can also endocytose foreign $\mathrm{Ag}$ and suppress cognate $\mathrm{T}$ cells in allogeneic, exogenous, and cancer Ag models $(16,19,20)$. The immunological suppressive capacity of LSECs was reported in an in vitro model $(12,21)$ as well as in vivo models $(22)$. In these studies, chimeric livers, produced by adoptive transfer of allogeneic LSECs, induced suppression of allo-specific $\mathrm{T}$ cells in vivo; however, the suppressive effect of LSECs was attenuated by anti-PD-L1 antibody $(\mathrm{Ab})$ during engraftment of allogeneic LSECs. Another study using a similar model, proved that LSECs have the ability to induce tolerance of carbohydrate reactive $\mathrm{B}$ cells through the $\mathrm{PD}-\mathrm{L} 1$ pathway by demonstrating that chimeric $\alpha 1,3$-galactosyltransferase gene knockout (GalT) mice in which Gal-deficient LSECs were replaced with wildtype LSECs by adoptive transfer, lost the ability to produce anti-Gal Abs even after repeated immunization (23). This result suggests that LSECs also contribute to establishment of spontaneous tolerization of $\mathrm{B}$ cells in ABO-blood type incompatible liver transplantation. In a mouse orthotopic liver transplantation model, it has been reported that PDL1 mediates the immune regulatory function of graft nonhematopoietic non-parenchymal cells including LSECs $(24,25)$. In this model, liver allografts from chimeric mice with $P D$ $L 1^{+/+}$hematopoietic cells and $P D-L 1^{-/-}$non-hematopoietic cells were rejected, whereas those from wild-type mice with $P D$ $L 1^{+/+}$hematopoietic cells and $\mathrm{PD}-\mathrm{L} 1^{+/+}$non-hematopoietic 


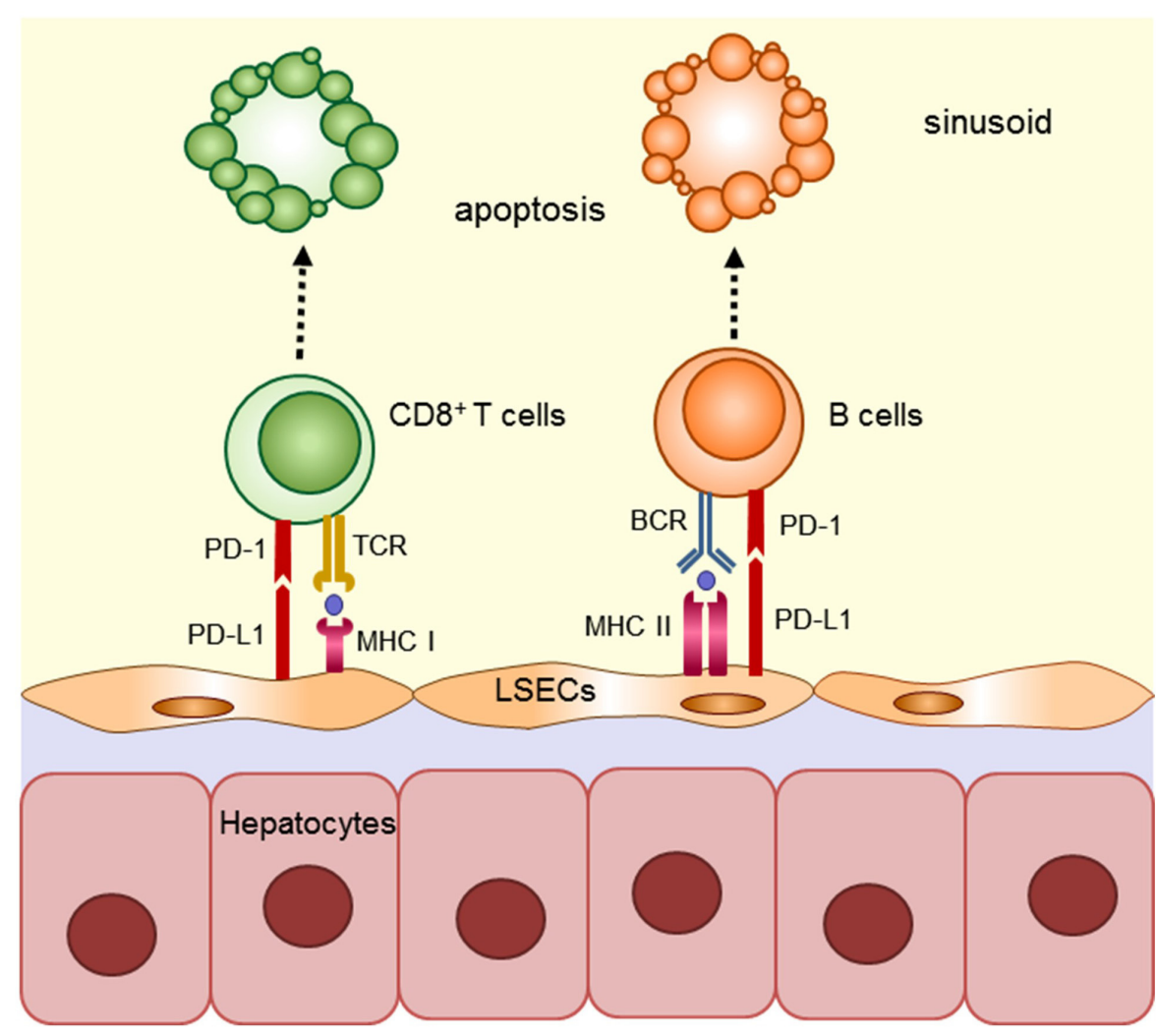

FIGURE 1 | Mechanism implicated in regulating anti-donor immune cells by LSECs in grafted liver. LSECs constitutively express classes I and II and have the capacity for Ag presentation. LSECs contribute to the establishment of immunological tolerance in grafted liver by promoting apoptosis of donor-MHC reactive $\mathrm{T}$ and $\mathrm{B}$ cells through Ag-presentation and PD-1/PD-L1 signaling.

cells were accepted in vivo, suggesting that $P D-L 1^{+/+}$nonhematopoietic cells, such as LSECs or stellate cells, likely contribute to the tolerogenicity of the liver via the PD-L1/PD1 axis. In summary, these results suggest that LSECs contribute to the establishment of immunological tolerance in grafted liver by promoting apoptosis of donor-MHC reactive $\mathrm{T}$ and $\mathrm{B}$ cells through Ag-presentation and PD-1/PD-L1 signaling (Figure 1).

Notably, both in a mouse model and clinical living related liver transplantation, we have recently reported that portal hypertension enhances alloimmune responses, likely due to the impaired immune-suppression capacity of LSECs (26). In these studies, we demonstrated that expression of molecules necessary for Ag presentation and PD-L1, and the suppressive capacities of LSECs were decreased in portal hypertension. These results also strongly imply that LSECs contribute to the establishment of tolerance status after liver transplantation and importance of control of portal hypertension for achieving tolerance in liver transplantation.

\section{Heptic Stellate Cells (HSCs)}

HSCs are pericytes found in the Disse space, which is a space between the sinusoid $s$ and hepatocytes. HSCs are classified as fibroblasts, and are well-described for their important role for hepatic fibrosis and storage of vitamin A. It has been recently shown that HSCs also function as APCs (27). HSCs express CD1d, MHC class II, and CD86, which are integral for APC, and present Ag to reactive $\mathrm{T}$ cells. It has been reported that mouse and human HSCs express PD-L1, and activated HSCs markedly upregulate PD-L1 expression and induce T cell-hyporesponsiveness in vitro $(28,29)$. This immunesuppressive effect of HSCs is triggered by IFN- $\gamma$ and regulates the MEK/ERK pathway (30). Furthermore, it has been recently reported that HSCs preferentially induce Foxp3 ${ }^{+}$Tregs by the production of retinoic acid (31). In an in vivo model, co-transplantation of HSCs effectively protects islet allograft from rejection through PD-L1 signaling (32). These results suggest that HSCs have immune suppressive features similar to LSECs and play an important role in tolerogenic status in the liver. Of note, HSCs may be related to pericytes or mesenchymal stem/stromal cells in vivo due to their genetic proximity and similarities of phenotype and differentiation potency (33-35). These cells have been shown to elicit very elaborate immunoregulatory effects (36-38). In fact, a phase I-II clinical study of infusion of MSC after deceased liver transplantation to achieve operational tolerance has been reported (39). This study also might encourage a clinical application of HSC. 


\section{OTHER BASIC MECHANISMS OF IMMUNE TOLERANCE IN LIVER TRANSPLANTATION INVOLVING BREG CELLS AND NKT CELLS}

\section{Regulatory B Cells}

Recent studies have shown the existence of a distinct subset of $B$ cells with immunomodulatory properties, which have been termed regulatory B cells (Bregs), analogous to Tregs. Bregs have been found to play a pivotal role in regulating immune responses involved in inflammation, autoimmunity, and malignancy (40). Their main mechanism of action is by promoting the development of Tregs while suppressing effector $\mathrm{CD}^{+}$and $\mathrm{CD}^{+} \mathrm{T}$ cells, primarily by secreting IL-10, IL-35, and transforming growth factor $\beta$ (TGF $\beta$ ), which produce donorspecific antibodies and induce antibody-mediated rejection. However, recent studies have indicated that Bregs, which possess antibody-independent effector functions, have the capacity to control or regulate immune responses to a transplanted organ $(41,42)$.

As one part of Breg cells, B cells were found to express PD-L1 and PD-L2, which are well-known to have a pivotal role in regulating autologous $\mathrm{T}$ cell-immune response in selfimmunity by engaging $\mathrm{PD}-1$, providing immune homeostasis and mediating the mechanisms of tolerance $(43,44)$. We have recently demonstrated that the unique B-1 cell subset expressing PD-L1 and PD-L2 inhibits alloimmune $\mathrm{T}$ cell responses in mice (45).

Although the role of Breg cells in immune tolerance in clinical liver transplantation remains to be elucidated, one study revealed that sirolimus could amplify Bregs and Tregs among LT recipients, which might be beneficial in mitigating the immune response (46). The role of Breg cells in liver transplantation is becoming increasingly understood, and tolerization relevant to Breg cells might be expected to be applied clinically.

\section{Natural Killer T Cells}

Invariant natural killer T cells (iNKT cells), which express an invariant $\mathrm{T}$ cell receptor (TCR) $\alpha$-chain and recognize lipids present on CD1d, secrete diverse cytokines (such as interferon- $\gamma$, IL-4, IL-5, IL-10, and IL-13) and influence many types of immune responses (47). In general, iNKT cells are non-circulating, tissueresident lymphocytes, but the prevalence of different iNKT cell subsets differs markedly between tissues, that is, the liver, lungs, adipose tissue, and intestine (48). Among these tissues, iNKT cells are most frequent in the liver in both mice and humans.

In organ/tissue transplantation, iNKT cells play a significant immune-regulatory role in the maintenance of transplant tolerance to allografts $(49-51)$. It has been demonstrated that CD40L/CD28 blockade fails to maintain tolerance to allograft in iNKT cell-deficient recipients mice, while peripheral transplant tolerance can be induced in wild-type recipients by that treatment (51). Consistently, it has been shown that liver allografts lacking iNKT cells manifested infiltration, hemorrhage and necrosis with significant reduction of graft survival and much less induction of tolerance compared with wild-type liver allograft in mice (52). Hence, iNKT cells, particularly donorliver resident iNKT cells, are found to be immune regulatory cells that play a vital role in inducing spontaneous tolerance after allogeneic liver transplantation. In addition, we have also demonstrated that iNKT cells play a significant role in the immunosuppressive effects induced by LSECs on T cells with indirect allospecificity (53).

\section{IMMUNOSUPPRESSION WITHDRAWAL TRIALS}

In 1993, Reyes et al. in the Pittsburgh group reported the first series of operational tolerant recipients whose allograft did not show functional deterioration after cessation of immunosuppressants (ISs) due to their mandatory requirements such as severe infection and malignancy (54). Operational tolerance is separately understood from immunological tolerance that is observed as no proof of immunological activity in the experimental model. After the Pittsburgh report, a total of 17 groups have reported their experience and trials (11 adult/4 pediatric/2 mix population) to pursue the ideal goal, transplant tolerance, which may allow the return of natural immunity and free them from the side effects of IS (Table 1) (54-75).

Two early trials at Pittsburgh by Dr. Starzl and King's college by Dr. Williams and their colleagues revealed that attempting complete IS withdrawal could be successful in some recipients (19 and 27.7\%, respectively), and long-surviving LT recipients were generally over-immunosuppressed (55-57). Since several experimental models have shown that donor chimerism can induce transplant tolerance (76-78), these trials and a randomized control trial (RCT) in Miami by Tryphonopoulos et al. (63) have assessed micro- and macrochimerism as mechanisms of operational tolerance. However, donor-chimerism was not proven to be a mechanism of clinical operational tolerance. Later, Eason et al. at the New Orleans tried early induction of operational tolerance and showed that it seemed difficult to succeed, but still feasible with regard to reversal rejection events and subsequent graft survival (62). A similar finding has been shown in a recent multicenter trial with strict selection criteria and withdrawal protocol (75). As another risk factor for failure of complete IS withdrawal, recent episodes of rejection, autoimmune-related original disease were reported in early studies, and these factors are recognized as standard exclusion criteria for recent IS withdrawal trials $(57,67)$. Operational tolerance in pediatric recipients presented by Dr. Feng and her colleagues in San Francisco seems to show a relatively higher success rate compared to adult cases. This may be because of their immature immune system, but one of the other reasons could be more living donor cases, particularly parents who share the haplotype of HLA. Actually, data from living donor-related recipients are limited in adults. It may be a good candidate for investigating the mechanism of operational tolerance.

Currently, two IS withdrawal trails supported by the Immune Tolerance Network (ITN) leaded by Dr. Nepom are in operation. Recent trials achieving relatively high success rates of withdrawal by using strict selection criteria (69-72) showed that time after transplantation and age of recipients are the most impactful 
TABLE 1 | Studies for spontaneous tolerance in liver transplantation.

\begin{tabular}{|c|c|c|c|c|c|c|c|c|c|c|c|c|c|}
\hline Institution & $\begin{array}{c}\text { Published } \\
\text { year }\end{array}$ & $\begin{array}{l}\text { Living/ } \\
\text { Cadaver }\end{array}$ & $\begin{array}{l}\text { Pediatric/ } \\
\text { Adult }\end{array}$ & Study design & $n$ & $\begin{array}{l}\text { Patient with } \\
\text { S.E. }\end{array}$ & $\begin{array}{l}\text { Baseline } \\
\text { biopsy }\end{array}$ & $\begin{array}{l}\text { Time since LT } \\
\text { (criteria) yr }\end{array}$ & IS regimen & Success rate & $\begin{array}{l}\text { Acute rejection } \\
\text { (Chronic } \\
\text { rejection) }\end{array}$ & $\begin{array}{l}\text { Graft } \\
\text { loss }\end{array}$ & Remarks \\
\hline \multirow[t]{2}{*}{ Pittsburgh } & $1993(54)$ & - & - & $\begin{array}{l}\text { Case series } \\
\text { reports }\end{array}$ & 6 & Yes & No & NA & NA & NA & NA & NA & $\begin{array}{l}\text { First series report from } \\
\text { Pittsburgh }\end{array}$ \\
\hline & $\begin{array}{l}1995(55) \\
1997(56)\end{array}$ & NA & Mix & Prospective & $\begin{array}{l}59 \\
95\end{array}$ & No & Yes & Mean 8.4 (>5) & $\begin{array}{l}14 \% \text { Aza, } 12 \% \text { Tac } \\
74 \% \text { CsA }\end{array}$ & 18/95 (19\%) & $25.4 \%$ (NR) & 0 & $\begin{array}{l}\text { Two of PBC developed } \\
\text { recurrence }\end{array}$ \\
\hline King's College & $1998(57)$ & Cadaver & Adults & Prospective & 18 & Yes & No & Median 7 (-) & CsA and Aza & $5 / 18(27.7 \%)$ & $28 \%(5.6 \%)$ & $\begin{array}{l}1 / 18 \\
(5.6 \%)\end{array}$ & $\begin{array}{l}\text { Fewer HLA mismatch was } \\
\text { associated with successful } \\
\text { withdrawal. Previous rejection } \\
\text { history and autoimmune } \\
\text { original disease are risk factor }\end{array}$ \\
\hline \multirow[t]{2}{*}{ Kyoto } & 2001 (58) & Living & Pediatric & $\begin{array}{l}\text { Partially } \\
\text { prospective }\end{array}$ & $26(63)$ & Partially yes & No & $\mathrm{NA}(>2)$ & Tac & 24/63 (38.1\%) & $12 \%(N R)$ & 0 & $\begin{array}{l}\text { Biopsy at } 4 \text { year after weaning } \\
\text { showed that } 2 \text { of } 11 \text { tolerant } \\
\text { recipients had substantial bile } \\
\text { duct atrophy and recovered } \\
\text { by tacrolimus reinduction }\end{array}$ \\
\hline & 2002 (59) & Living & Mix & $\begin{array}{l}\text { Prospective }+ \\
\text { retrospective }\end{array}$ & 115 & Partially yes & No & $\mathrm{NA}(>2)$ & Tac & 16/67 (23.9\%) & $\begin{array}{l}\text { Non-protocol } 25 \% \\
\text { Protocol } 11.9 \%\end{array}$ & 0 & $\begin{array}{l}\text { None of clinical characteristics } \\
\text { was identified as predictor of } \\
\text { successful weaning }\end{array}$ \\
\hline Marcia & $2003(60)$ & Cadaver & Adult & Prospective & 9 & No & Yes & Median 5.1 (>2) & СУА & $3 / 9(33 \%)$ & $22 \%(N R)$ & 0 & $\begin{array}{l}\text { Endothelial cell chimerism } \\
\text { seems to have nothing to do } \\
\text { with the induction of clinical } \\
\text { tolerance in liver transplant } \\
\text { patients }\end{array}$ \\
\hline Stanford & 2004 (61) & NA & Pediatric & Retrospective & 38 & Yes & No & NA & $\begin{array}{l}\text { Steroid+CNI } \\
\text { (Tac92\%, CyA 8\%) }\end{array}$ & 8/38 (20.5\%) & $55.3 \%$ (5.3\%) & $\begin{array}{c}2 / 38 \\
(5.3 \%)\end{array}$ & $\begin{array}{l}\text { Two patients were } \\
\text { retransplanted for chronic } \\
\text { rejection }\end{array}$ \\
\hline New Orleans & 2005 (62) & Cadaver & Adult & Prospective & 18 & No & No & $(>0.5)$ & Tac & 1/18 (5.6\%) & $61 \%(N R)$ & 0 & $\begin{array}{l}\text { Early induction of operational } \\
\text { tolerance seems to be difficult }\end{array}$ \\
\hline Miami & $2005(63)$ & Cadaver & Adult & $\begin{array}{l}\mathrm{RCT} \text { (donor } \\
\mathrm{BM} \text { ) }\end{array}$ & 105 & No & No & Mean 4 (>3) & $85 \%$ Tac $14 \%$ CsA & $0 \%$ & $67 \%(1.9 \%)$ & $\begin{array}{c}1 / 105 \\
(0.95 \%)\end{array}$ & $\begin{array}{l}\text { Donor bone marrow infusion } \\
\text { did not help successful } \\
\text { completion of withdrawal }\end{array}$ \\
\hline Rome & $\begin{array}{l}2006(64) \\
2008(65) \\
2013(66)\end{array}$ & Cadaver & Adult & Prospective & 34 & No & Yes & Mean 5.3 (>1) & CsA monotherapy & 8/34 (23.4\%) & $76.4 \%$ (NR) & 0 & All HCV related recipients \\
\hline Israel & 2007 (67) & NA & Adult & RCT & 26 & No & No & $\begin{array}{l}\text { Mean } 4.3 \text { vs. } 5.0 \\
(>2)\end{array}$ & $\begin{array}{l}\text { CsA +/-Aza, } \\
\text { (Plednisone) }\end{array}$ & $2 / 26(7.7 \%)$ & $\begin{array}{l}\text { UDCA+ } 43 \% \\
\text { UDCA- } 75 \%\end{array}$ & 0 & $\begin{array}{l}\text { 3/4 AlH recipients had } \\
\text { recurrence }\end{array}$ \\
\hline Korea & $2009(68)$ & Mix & Pediatric & Retrospective & 5 & Yes & No & Median 3.8 & NA & - & NR & 0 & $\begin{array}{l}\text { Long term stable graft } \\
\text { function and no rejection }>1 \\
\text { yr were favorable findings for } \\
\text { successful withdrawal }\end{array}$ \\
\hline
\end{tabular}


TABLE 1 | Continued

\begin{tabular}{|c|c|c|c|c|c|c|c|c|c|c|c|c|c|}
\hline Institution & $\begin{array}{c}\text { Published } \\
\text { year }\end{array}$ & $\begin{array}{l}\text { Living/ } \\
\text { Cadaver }\end{array}$ & $\begin{array}{l}\text { Pediatric/ } \\
\text { Adult }\end{array}$ & Study design & $n$ & $\begin{array}{l}\text { Patient with } \\
\text { S.E. }\end{array}$ & $\begin{array}{l}\text { Baseline } \\
\text { biopsy }\end{array}$ & $\begin{array}{l}\text { Time since LT } \\
\text { (criteria) yr }\end{array}$ & IS regimen & Success rate & $\begin{array}{l}\text { Acute rejection } \\
\text { (Chronic } \\
\text { rejection) }\end{array}$ & $\begin{array}{l}\text { Graft } \\
\text { loss }\end{array}$ & Remarks \\
\hline UCSF & 2012 (69) & Living & Pediatric & $\begin{array}{l}\text { Multi-center } \\
\text { prospective }\end{array}$ & 20 & No & Yes & Mean 7.7 (>3) & CNI monotherapy & $12 / 20(60 \%)$ & $36.8 \%$ (NR) & 0 & $\begin{array}{l}\text { Later initiation of IS withdrawal } \\
\text { after transplantation and less } \\
\text { portal inflammation and total } \\
\text { C4d score on screening } \\
\text { biopsy were associated with } \\
\text { successful withdrawal }\end{array}$ \\
\hline Pamplona & $2013(70)$ & Cadaver & Adult & Prospective & 24 & Yes & Yes & Median 9.3 (>3) & NA & $15 / 24(62.5 \%)$ & $4.1 \%(41 \%)$ & 0 & $\begin{array}{l}\text { Tolerant patients had a longer } \\
\text { median interval between } \\
\text { transplantation and inclusion } \\
\text { in the study (156 vs. } 71 \\
\text { months) }\end{array}$ \\
\hline \multirow[t]{2}{*}{ Barcelona } & $2013(71)$ & Cadaver & Adult & $\begin{array}{l}\text { Multi-center } \\
\text { prospective }\end{array}$ & 102 & No & Yes & Median 8.6 (>3) & $\begin{array}{l}\text { CNI mTOR inhibitor } \\
\text { CSB }\end{array}$ & 41/102 (40.2\%) & $56 \%$ (NR) & 0 & $\begin{array}{l}\text { Time since transplantation, } \\
\text { recipient age, and male } \\
\text { gender were independent } \\
\text { factor for successful } \\
\text { withdrawal }\end{array}$ \\
\hline & $2014(72)$ & Cadaver & Adult & $\begin{array}{l}\text { Multi-center } \\
\text { prospective }\end{array}$ & 32 & No & Yes & Median 7.2 (>3) & $\begin{array}{l}\mathrm{CNI}+/-\mathrm{MMF} \text { or } \\
\mathrm{CBS}\end{array}$ & $17 / 34(50 \%)$ & $44.1 \%(N R)$ & 0 & $\begin{array}{l}\text { Persistent viral infections exert } \\
\text { immunoregulatory effects that } \\
\text { could contribute to the } \\
\text { restraining of alloimmune } \\
\text { responses }\end{array}$ \\
\hline Taipei & 2015 (73) & Mix & Pediatric & $\begin{array}{l}\text { Single center } \\
\text { retrospective }\end{array}$ & 16 & No & Yes & $\begin{array}{l}(>1 \text { for } T x<1,> \\
2 \text { for } T x>1)\end{array}$ & Tac monotherapy & $5 / 15(33 \%)$ & $46.7 \%$ (NR) & 0 & $\begin{array}{l}\text { Early recruitment was } \\
\text { favorable factor predicting } \\
\text { operational tolerance }\end{array}$ \\
\hline Chicago & 2019 (74) & Cadaver & Adult & Prospective & 15 & No & Yes & Mean 6.7 (>3) & Silorimus & 8/15 (53.3\%) & $40 \%$ (NR) & 0 & $\begin{array}{l}\text { mTOR inhibitor withdrawal } \\
\text { had similarly succeeded in } \\
\text { comparison with CNI } \\
\text { withdrawal }\end{array}$ \\
\hline Pennsylvania & $2019(75)$ & Cadaver & Adult & $\begin{array}{l}\text { Multi-center } \\
\text { RCT }\end{array}$ & 77 & No & Yes & Median 18 (>3) & $\begin{array}{l}\text { Tac (91) CsA (2), } \\
\text { MMF(2) }\end{array}$ & 10/77 (13\%) & $40.3 \%$ (NR) & 0 & $\begin{array}{l}\text { Withdrawal showed likely less } \\
\text { eventful than maintenance } \\
\text { group }\end{array}$ \\
\hline
\end{tabular}

S.E., side effect; Aza, azathioprine; Tac, tacrolimus; CSA, cyclosporine A; NR, not reported; NA, not assessed; CNI, calcineurin inhibitor; RCT, randomized control study; CSB, costimulatory blockade; MMF, mycophenolate mofetil. 
and common clinical factors of operational tolerance. These studies also suggested that exhausted $\mathrm{T}$ cells against hepatitis $\mathrm{C}$ virus $(\mathrm{HCV})$ in $\mathrm{HCV}$-related recipients and hyporesponsive $\mathrm{T}$ cells against polyclonal stimulation prior to withdrawal could contribute to the establishment of tolerance $(70,72)$. Based on these findings, multicenter IS withdrawal trial is currently being conducted by Dr. Markmann and his colleagues in Boston (NCT02533180, OPTIMAL) for evaluating donorspecific immune senescence and exhaustion as biomarker of operational tolerance in adults. Dr. Sanchez-Fueyo and his colleagues in Spain is conducting another trial (NCT02498977, LIFT) with a similar structure, but focused on exploring biomarkers in transcriptional signatures to identify operational tolerant recipients. The results of both trials could open a new gate to understand the mechanism of operational tolerance.

\section{IMPACT OF DSA ON IMMUNOSUPPRESSION WITHDRAWAL}

The deleterious effect of donor-specific antibody (DSA) on LT recipients is increasingly recognized, but has not been well-defined. The DSA may cause two types of antibodymediated rejection (AMR): one is acute AMR resulting in immunologically adverse consequence because of preformed DSA usually accompanied by cellular rejection in the early postoperative period, and the other is chronic AMR causing progressive fibrosis in the late phase after liver transplantation. A retrospective cohort study has shown that de novo DSA (dnDSA) is associated with rejection, graft loss, and patient death after liver transplantation, and one of the risk factors for developing dnDSA is inadequate IS (79). However, a recent IS withdrawal trial in adult primary LT patients (A-WISH trial, NCT00135694) has shown that there was no difference in the prevalence of dnDSA (especially HLA class II dnDSA) between IS maintenance and IS minimization ( $44.4 \%$ vs. $51.7 \%$, respectively), and the prevalence was the highest after IS withdrawal was completed $(66.7 \%)(75,80)$. Interesting findings in prevalence have been reported that the majority $(78.7 \%)$ of dnDSA was developed against HLA-DQ Ags, which included DQB1 (57.4\%) and DQA1 $(21.3 \%)$ chains independent of IS status, and dnDSA against HLA class I Ags increased only when patients were free of IS. From the view of pathogenicity, dnDSA detected in patients who failed IS withdrawal may be highly pathogenic compared to that in patients under IS maintenance and IS-free according to the prevalence of acute rejection rate $(71.4,25.0$, and $16.7 \%$, respectively) (80).

It is well-recognized that different IgG subclasses have unique characteristics, such as complement fixation potential or cellular binding capacity through Fc receptors (FcRs), which may affect their pathologic potential. IgG3 is known as the strongest complement activating capacity, followed by IgG1 and IgG2, while IgG4 is the only subclass that fail to fix complement. IgG3 and IgG1 bind to all three classes of FcRs (FcRI, FcRII, and FcRIII), while IgG4 binds to FcRII and FcRIII, and IgG2 binds only FcRII (81). These binding abilities have the potential to trigger functions such as antibody-dependent cell cytotoxicity, cytokine production, intracellular signaling, and initiation of cell recruitment and degranulation with various immune mediators (macrophages, NK cells, neutrophils, and B cells) (82). Jackson et al. recently examined whether DSA IgG subclass characteristics could identify subjects whose liver allografts exhibit subclinical graft injury with samples from a multicenter IS withdrawal study for pediatric LT recipients (iWITH, NCT01638559) (83). They reported that the HLA-class II IgG4 DSA profile was associated with a higher HLA mismatch, a subclinical histopathological phenotype characterized by interface activity, and a tissue transcriptional profile of rejection. Substantial IgG subclass analysis for DSA in a prospective study is expected for better understanding and management of the dynamic evolution of DSA maturation, mechanisms of injury, and entry points for intervention (84). DSA is produced against HLA mismatches and HLA Ags has been reported to have structural epitope that dominate the strength and specificity of binding antibody (85). Recently, it has been reported that HLA class II epitope mismatch, which was analyzed by HLA Matchmaker or the predicted indirectly recognizable human leukocyte antigen epitopes algorithm (PIRCHE-II), is correlated with a high risk of dnDSA formation after liver transplantation $(86,87)$. By using more detail data on HLA class II epitope mismatch related to donor recipients, the eligibility criteria for patient selection in early IS minimization or IS withdrawal trials may be sophisticated (12).

\section{IMMUNE MONITORING TO PERSONALIZE IMMUNOSUPPRESSION TOWARD TOLERANCE}

Liver transplant recipients receive immunosuppressive therapy according to empirical protocols. Immune monitoring comprises candidate biomarkers capable of reflecting the donor-specific and non-specific net-activating state of the immune system, and can be dissected into tissue, cell, protein, and gene profiles with graft or systemic samples (Figure 2). Here, we summarize the potential tool for immune monitoring to personalize immunosuppressive therapy potentially toward operational tolerance.

As clinical information, histological findings regarding inflammation and fibrosis are the gold standard for the diagnosis of rejection. Intensive molecular analyses of biopsy specimens have shown that immune regulatory markers, such as IL-10, PD1, PDL1, BATF, TGF $\beta$, and Foxp3 were significantly higher in tolerant patients (72). Intra-graft iron metabolism has also been identified in tolerant samples (88). Immunofluorescence staining revealed transient accumulation of $\mathrm{CD}_{4}^{+} \mathrm{FOXP}^{+}$cells in tolerant recipients, along with the upregulation of immune regulatory genes (89). Although biopsy-based assessments are a valuable source of information on immunological status, it can be harmful because of their potential risk of complications. As candidates of safer biomarkers for successful withdrawal, the immune phenotype of peripheral blood has also been diligently investigated. Pittsburgh group reported that the increase in the ratio of plasmacytoid DCs to monocytoid DCs in peripheral blood was associated with successful withdrawal (90). Consistent 


\begin{tabular}{|c|c|c|}
\hline \multirow{3}{*}{ Tissue } & Graft biopsy & Systemic \\
\hline & Histology & Peripheral blood \\
\hline & \multicolumn{2}{|c|}{ Immune cells } \\
\hline \multirow{3}{*}{ Cell } & \multirow{3}{*}{$\begin{array}{l}\text { Regulatory cells } \\
\text { Effector cells }\end{array}$} & \multirow{3}{*}{$\begin{array}{c}\text { Function } \\
\text { Allo-response; MLR } \\
\text { Proliferation } \\
\text { Cytokine } \\
\text { Activation marker } \\
\text { TCR repertoire }\end{array}$} \\
\hline & & \\
\hline & & \\
\hline \multirow{4}{*}{ Protein } & & Serum \\
\hline & & \multirow{2}{*}{$\begin{array}{cc}\text { HLA antibody } & \text { Cytokine } \\
\text { Chemokine } & \text { Metabolite }\end{array}$} \\
\hline & & \\
\hline & \multicolumn{2}{|c|}{ RNA } \\
\hline \multirow{3}{*}{ Gene } & \multicolumn{2}{|c|}{ Quantitative gene expression } \\
\hline & \multicolumn{2}{|c|}{ DNA } \\
\hline & GWAS & CGA (Polymorphism) \\
\hline \multicolumn{3}{|c|}{$\begin{array}{l}\text { FIGURE } 2 \text { | Potential immune monitoring application for tolerance in liver } \\
\text { transplantation. This figure summarizes the readouts being investigated for } \\
\text { their potential use for immune monitoring to understand what is happening in } \\
\text { the allograft and predict tolerance. Histological assessment is a direct readout } \\
\text { of allografts, but it is not enough to predict tolerance. Systemic information } \\
\text { from peripheral blood has been investigated as an alternative because of its } \\
\text { less invasive availability. The readouts were categorized into four groups based } \\
\text { on their level of information, tissue, cell, protein, and gene. MLR, mixed } \\
\text { lymphocyte reaction; GWAS, genome-wide association study; CGA, candidate } \\
\text { gene approach. }\end{array}$} \\
\hline
\end{tabular}

with this finding, a study with a mammalian target of rapamycin (mTOR) inhibitor showed a higher proportion of tolerogenic DCs in tolerant recipients (74). An increasing number of regulatory $\mathrm{T}$ cell subsets (Tregs and gamma-delta T cells) and NK cells in peripheral blood are associated with tolerant recipients, which is consistent with their gene signatures $(58,65,74,91)$. A recent report has shown the kinetics of increasing Tregs/Th17 cell ratio over the clinical course as a predictor of the development of tolerance (92). These have the potential to be monitoring tools for tolerance, but further investigations are needed to validate their capacities. Pioneering studies for transplant tolerance has been conducted by "The One Study" consortium leading by Dr. Geissler and his colleagues. This consortium conducted harmonized cell therapy studies by multi-center to induce tolerance with standard immunosuppressive regimen and immune monitoring protocol, which allow to analyze different trial data under same platform. These approach also would be great helpful to build solid and universal foundation in clinical tolerance, which is observed to a limited extent.

Along with the immune phenotype, functional assays have been investigated mainly using mixed lymphocyte reaction (MLR) assays with various readouts. One-way MLR with whole peripheral blood mononuclear cells (PBMCs) has been often attempted to use as clinical assay monitoring donor specific response. However, MLR readout with tritiated thymidine incorporation shows little predictive value because of its low level of reproducibility (93). ELISPOT and qPCR-based detection of cytokines in MLR assay showed sensitive results, but readout of limited cytokines from bulk cultured cells may be difficult to interpret as representative of the entire alloresponse (94-96). Non-toxic intracellular fluorescent dyes such as carboxyfluorescein diacetate succinimidyl ester (CFSE) stably stain intracellular proteins, and the fluorescence of each stained cell segregates equally to daughter cells upon cell division, resulting in sequential halving of cellular fluorescence intensity with each successive generation (97). This sequential halving of fluorescence can be analyzed to track cell division in populations of proliferating cells using intensity based analysis by flow cytometry (FACS) even in alloresponse which is comparatively lower incidence. Additionally, FACS analysis provides opportunity to assess detail phenotype of proliferating cell along with number of cells originally proliferated, that is halving of fluorescence is visualized as distinct peaks or populations of cells and can be used to track cell division in populations of proliferating cells. This allows phenotypic analysis of proliferating cells in addition to determining the number of cells produced in each generation by multicolor FACS analysis, that is, the precursor frequency of each $\mathrm{CD} 4^{+}$and $\mathrm{CD} 8$, the precursor frequency of each $\mathrm{CD}^{+}$and $\mathrm{CD}^{+} \mathrm{T}$ cell (and others) can be quantified separately (Figure 3A). The lack of proliferation in anti-donor MLR reflects the suppression of the anti-donor response (99). We have previously reported that optimization of immunosuppressive therapy based on the CFSEMLR assay provides a low incidence of acute rejection, reduction of infectious complications, and helps in monitoring anti-selfresponse of $\mathrm{CD}^{+} \mathrm{T}$ cells, which predicts the recurrence of autoimmune liver diseases after LT (98, 100-102) (Figure 3B). In addition, CFSE-MLR-based immune monitoring has been proven to be a useful tool to personalize IS therapy, especially for LT patients with impaired renal function and HBV-infected LT patients requiring post-transplant HBV vaccination (103, 104). The benefit of CFSE-MLR immune-monitoring can be applied to $\mathrm{T}$ cell receptor (TCR) repertoire analysis by highthroughput sequencing. The Colombia group developed a TCR sequencing-based analysis of responding $\mathrm{T}$ cells in CFSE-MLR to identify and track a significant fraction of alloreactive $\mathrm{T}$ cell repertoire in any donor-recipient pair $(105,106)$. They have shown that liver-induced clonal deletion detected by tracking alloreactive TCR clones in pre-transplant MLR may contribute to achieving tolerance in LT recipients (107). Furthermore, another potentially beneficial application of MLR is the detection of activating induced markers and cytokines. CD154 (CD40L) has been reported to rapidly upregulate Ag-specific activating markers of $\mathrm{T}$ cells $(108,109)$. Upregulation of CD154 in $\mathrm{T}$ cells in MLR with donor stimulator was reported as a risk factor for rejection in pediatric liver transplant recipients (110). Like CD154, CD137 (4-1BB) has been reported as a specific activation-induced molecule on $\mathrm{T}$ cells (111). Interestingly, their combination, $\mathrm{CD} 154^{\text {neg }} \mathrm{CD} 137^{+}$, in $\mathrm{CD} 4^{+} \mathrm{T}$ cells have been reported to be representative of activated Tregs under Ag stimulation, including allo-stimulation, suggesting that it could 
be a candidate for monitoring alloreactive $\mathrm{T}$ cell responses in $\mathrm{LT}$ recipients $(112,113)$.

\section{IMMUNE TOLERANCE MEDIATED BY TREGS}

\section{Applicability of Treg Cell Therapy in Liver Transplantation}

Since the discovery of suppressive $\mathrm{T}$ cells and markers, Tregs (mostly defined as $\mathrm{CD} 4^{+} \mathrm{CD} 25^{+} \mathrm{FOXP}^{+}$) have been shown to be key mediators in the induction and maintenance of immune tolerance through multiple mechanisms (114-116). Together with these accumulating findings in basic science and clinically reported footprints e.g., the number of Tregs are increasing in tolerant recipients, Treg-based cell therapy has been attempted for tolerance in the field of transplantation. Initial attempts have been made in the field of bone marrow transplantation and have shown the feasibility of transferring polyclonally expanded Tregs for graft vs. host disease (GVHD) prophylaxis (117119). Together with promising rationale, several clinical trials have been conducted in LT recipients. Key considerations of this cell therapy are: (1) timing to infuse the cell product, (2) induction therapy to make space for adoptive Tregs, (3) cell component, whether Treg-enriched cell product or isolated Tregs for culturing, and (4) Ag specificity during expansion, polyclonal or donor specific (Table 2). In 2016, the Hokkaido University group demonstrated the impact of Treg-enriched cell therapy for inducing operational tolerance in 10 living donor LT patients (120). Autologous Treg-enriched cells were cultured in MLR in the presence of CD80/86 costimulatory blockade, and the cell product was administered after preconditioning with cyclophosphamide at early post-transplant period. Although three recipients with autoimmune liver disease developed cellular rejection during immunosuppressant weaning, the other seven (70\%) recipients were successfully weaned off immunosuppressive drugs 18 months after liver transplantation. In spite of a small cohort, the result that all tolerant patients maintained normal graft function without immunosuppressive drugs for over 5 years is promising for Treg cell therapy for tolerance induction (121). Currently, clinical studies with isolated Tregs, rather than bulk cultured cells, are in operation. The King's college group is running a phase I/II clinical trial with a polyclonal expanded Treg isolated by a magnetic isolation system in LT patients with antithymocyte globulin (ATG) pre-conditioning (NCT02166177). No serious adverse events have been observed to date (122). The UCSF group conducted clinical trials using donor alloAg reactive Tregs (darTregs) cultured with donor-derived stimulators (NCT02188719). The protocol includes the use of ATG before the infusion of donor allo-Ag reactive Tregs (123). The Massachusetts General Hospital (MGH) group is employing costimulatory blockade-induced allospecific Tregs that are generated in short-term MLR with belatacept and isolated by magnetic isolation before administration. These three trials reduced the calcineurin inhibitor (CNI) regimen with the

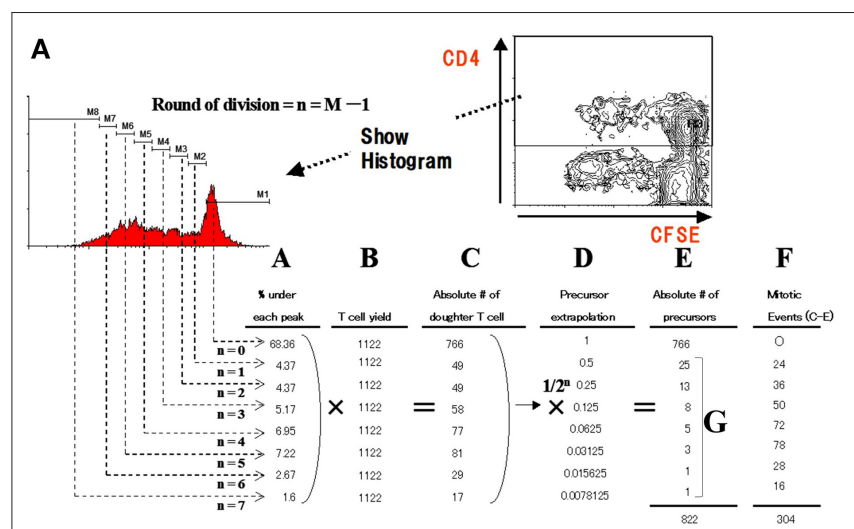

Precursor frequency $=$ reactive precursor $(G) /$ absolute precursor $(E)$ Mitotic Index (MI) = mitotic events (F) / absolute precursor (E) Stimulation Index $=$ allo MI/ auto MI

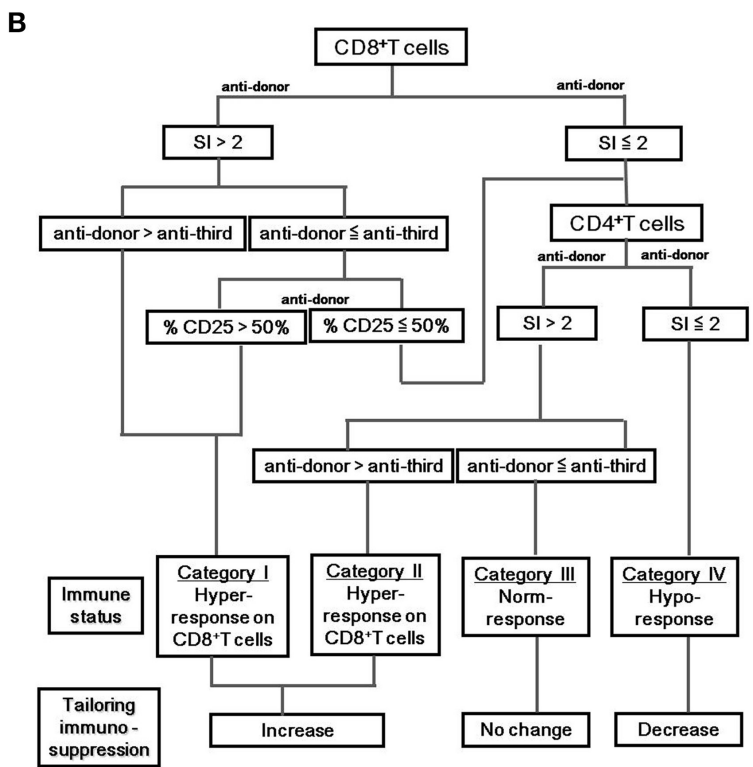

FIGURE 3 | CFSE-MLR for immune monitoring in transplantation. (A) Intensity-based analysis of mixed lymphocyte reaction assay with CFSE dye (CFSE-MLR) provide quantitative estimation of the alloresponse. In brief, the plot and histogram show the gating strategy for $\mathrm{CD} 4^{+}$proliferating cells. Cell division are gated by the rationale that the CFSE fluorescence intensity shows the half-value from former generation. (A) Percentage of CD4+ T cell events in each division, (B) T cell yield, (C) the number of daughter $T$ cells that had divided $n$ times (A multiply B), (D) precursor extrapolation Using mathematical relationship, the number of division precursors $(E, G)$ is extrapolated from the number of daughter cells of each division and from mitotic events (F). These values are used to calculate precursor frequency and mitotic index (MI). As normalized quantitative estimation, stimulation index are calculated by dividing Mls of allogeneic combinations by Mls of autologous controls. (B) Algorithm to estimate anti-donor alloreactivity in liver transplant recipients. The immune reactivity of liver transplantation recipients is classified into four categories. By analyzing the proliferation and CD25 expression of the $\mathrm{CD}^{+}$and $\mathrm{CD} 8^{+} \mathrm{T}$-cell subsets in response to anti-donor and anti-third party stimuli, the immune status is categorized as hypo-, normo-, or hyper-responsive. In recipients with hyper-response on either $\mathrm{CD} 4^{+}$or $\mathrm{CD} 8^{+} \mathrm{T}$ cells, immunosuppressants consider to be increased. In patients with normo-response, immunosuppressant tapering is abandoned. Only in patients with hypo-response, immunosuppressant therapy can be tapered off (98). SI, stimulation index. 
addition of an mTOR inhibitor before attempting complete IS withdrawal. Since clinical-grade manufactured Tregs cells are challenging, the King's college group treated 3 recipients finally out of the initial 23 and the USCF group's trial was terminated because of the manufacturing problem. USCF is conducting another trial, the ARTEMIS trial (NCT02474199), which has a different design, to aim at the reduction of CNI in patients with stable liver graft function in 2-6 years after LT with darTregs (123). It remains unclear when and what kind of Treg cell therapy is beneficial for LT recipients. Ongoing trials may clarify some points, but a systematic approach to investigate the best option may be needed.

\section{mTOR Inhibitor for Tolerance and Treg Expansion}

Currently, a CNI-based regimen is widely employed as standard IS therapy for the management of liver transplantation. One of the most problematic side effects is nephrotoxicity of CNIs because LT candidates frequently have a variety of degrees of renal dysfunction, and chronic renal failure has a negative impact on long-term outcomes. The strategy of early CNI minimization and mTOR inhibitor maintenance has been attempted to achieve better renal function after liver transplantation. Meta-analysis and recent RCTs have shown a protective effect on renal function by converting CNIs into mTOR inhibitor, but also high frequency of rejection compared to conventional CNI-based therapy, suggesting that selected patients could receive the benefit of mTOR inhibitor conversion (124-126). The mTOR signaling pathway through PI3K/AKT is widely utilized in the regulation of cellular activity in immune cells and cancer cells. mTOR inhibitors have been reported to have therapeutic effects on hepatocellular carcinoma (HCC) through multiple mechanisms, including direct antitumor effects and immune regulation (127129). According to the antitumor effect, LT recipients with HCC may be good candidates for mTOR inhibitor regimen (130). Another topic in the transplantation field of mTOR signaling is the impact on Treg stability and function, usually mTOR inhibition recognized as favorable effects (131). One recent IS withdrawal trial has been conducted expecting this "Treg friendly effect" to induce operational tolerance (74). Further investigation is required to elucidate the clinical application of mTOR inhibitors for transplantation tolerance.

\section{OUTLOOK ON EMPLOYING SNPS AND miRNAs FOR TOLERANCE}

Genetic factors have been reported to be involved in the mechanisms of transplant tolerance and rejection (132). Here, we summarize recent advances in genetics and genomics, particularly single nucleotide polymorphisms (SNPs) and microRNAs (miRNAs), and their roles intolerance after LT.

\section{Genome-Wide Association Studies (GWAS)}

Recent GWAS have established the genes and variants associated with outcomes in transplantation patients. Multiple GWAS have been conducted since 2016 on solid-organ transplantation, 
including acute rejection in renal transplantation, posttransplant malignancy in heart or renal transplantation, long-term allograft function, and new-onset diabetes mellitus after renal transplantation; however, there are no GWASs on liver transplantation $(96,132)$.

\section{Candidate Gene Approaches (CGA)}

The candidate gene approach has been applied in liver transplantation by conducting genetic association studies focusing on associations between immune-associated genetic variation and graft survival/rejection incidence. HLA-G, a non-classical HLA-class, has been associated with increased graft survival and decreased number of rejection cases (133-135). It is also known that HLA-G is capable of inducing a new generation of regulatory Tregs (136). A recent study has demonstrated that 14-bp ins/ins and +3142GG genotypes of HLA-G, which seem to be of serious importance for HLA-G expression, in LT recipients are involved in a low risk of acute rejection in liver transplantation, suggesting that LT recipients with a lower for developing an acute rejection may be identified by application of these genotypes as biomarkers (137). Another report has shown that the donor liver tissue-derived CYP3A5 rs776746 and small ubiquitin-like modifier 4 (SUMO4) rs237025 SNPs are associated with tacrolimus pharmacokinetics in the early period after LT, suggesting that combined evaluation of these donor genotypes may help determine the withdrawal or elimination of tacrolimus (138). We have also reported that the FOXP3 gene rs3761548 A/C SNP in living donor LT recipients is significantly concerned with susceptibility to steroid-resistant acute rejection and dnDSA formation, suggesting that the IS regime and/or anti-rejection treatment regimen should be adjusted on an individual basis by identifying FOXP3 SNPs (139). These genetic association studies may hopefully provide immune-related SNPs that can be useful markers to reduce or withdraw immunosuppressive drugs.

\section{miRNAs as Biomarkers}

miRNAs, which are $\sim 20-22$ nucleotide single-stranded RNA species, and play a central role in the regulation of proteincoding genes, are also emerging as robust biomarkers for assessing allograft status. Millán et al. have reported that plasma miRNAs can serve as early non-invasive prognostic and diagnostic biomarkers for T-cell mediated acute rejection in LT recipients, that is, miR-155-5p regulates the differentiation of $\mathrm{CD}^{+}{ }^{+} \mathrm{T}$ cells into Th cells and IFN- $\gamma$ production in human $\mathrm{T}$ and NK cells, and miR-181a levels modulate $\mathrm{T}$ cell receptor sensitivity and intensity of signaling (140). Hence, the plasma levels of miR-155-5p and miR-181a-5p after LT potentially help identify patients for IS minimization. Revilla-Nuin et al. have reported a set of differentially expressed miRNAs in tolerant recipients after liver transplantation that might promote and control the activation of Tregs necessary to develop operational tolerance (141). Their study showed that miR95, miR24, miR31, miR146a, and miR155 were expressed more in tolerant than in non-tolerant recipients, and were positively correlated with activated Treg markers. These five miRNAs were upregulated in the peripheral blood of LT recipients, and the transcription factor Foxp3 was associated with the miRNA profiles. miR155 is constitutively expressed in Tregs; Foxp3 binds to the promoter of miR155 in the B cell integration cluster and maintains the elevated levels of miR155 required for Treg proliferation. Furthermore, Vitalone et al. reported increased expression of miR-142-5p and miR-181a in tolerant livers in an allogeneic rat LT model (142). Morita et al. have also identified miRNAs involved in acute rejection and spontaneous tolerance in murine hepatic allografts (143). They found that miR-146a, 15b, 223, 23a, 27a, 34a, and 451 were upregulated in the allogenic liver grafts compared with the expression observed in the syngeneic grafts, whereas miR-101a, 101b, and 148a were downregulated, demonstrating the change of miRNAs in the allografts and may suggest the role of miRNAs in the induction of tolerance after liver transplantation.

\section{CONCLUSION}

Progresses in immunosuppressive therapy have efficiently reduced the incidence of acute rejection of liver allograft. However, life-long IS has inevitably led to substantial morbidity and mortality. Thus far, trial and error have been attempted to minimize or even withdraw immunosuppressants in select patients. These attempts would be more successful through the establishment of reliable immune-monitoring methods and biomarkers. In addition, deliberate immunomodulatory interventions would further improve the outcome of these attempts. This review has summarized our knowledge of mechanisms underlying immune-tolerance induced after liver transplantation and prospective strategies to intentionally complete withdrawal of IS treatment.

\section{AUTHOR CONTRIBUTIONS}

NT participated in the role of drafting and revising. MO, HT, $\mathrm{KI}, \mathrm{YT}$, and TO participated in roles of writing original draft. $\mathrm{HO}$ participated in roles of concepts, design, and drafting and revising. All authors contributed to the article and approved the submitted version.

\section{FUNDING}

This work was supported by the Japan Agency for Medical Research and Development under award number JP20ek0510029.

\section{ACKNOWLEDGMENTS}

We thank all the current and former clinical and research staffs in Department of Gastroenterological and Transplantation Surgery. 


\section{REFERENCES}

1. Calne RY, Sells RA, Pena JR, Davis DR, Millard PR, Herbertson BM, et al. Induction of immunological tolerance by porcine liver allografts. Nature. (1969) 223:472-6. doi: 10.1038/223472a0

2. Zimmermann FA, Davies HS, Knoll PP, Gokel JM, Schmidt T. Orthotopic liver allografts in the rat. The influence of strain combination on the fate of the graft. Transplantation. (1984) 37:406-10. doi: 10.1097/00007890-198404000-00019

3. Qian S, Demetris AJ, Murase N, Rao AS, Fung JJ, Starzl TE. Murine liver allograft transplantation: tolerance and donor cell chimerism. Hepatology. (1994) 19:916-24. doi: 10.1002/hep.1840190418

4. Kamada N, Davies HS, Roser B. Reversal of transplantation immunity by liver grafting. Nature. (1981) 292:840-2. doi: 10.1038/292840a0

5. Lu L, Rudert WA, Qian S, McCaslin D, Fu F, Rao AS, et al. Growth of donor-derived dendritic cells from the bone marrow of murine liver allograft recipients in response to granulocyte/macrophage colony-stimulating factor. J Exp Med. (1995) 182:379-87. doi: 10.1084/jem.182.2.379

6. Yokota S, Yoshida O, Ono Y, Geller DA, Thomson AW. Liver transplantation in the mouse: insights into liver immunobiology, tissue injury, and allograft tolerance. Liver Transpl. (2016) 22:536-46. doi: 10.1002/lt.24394

7. Steptoe RJ, Fu F, Li W, Drakes ML, Lu L, Demetris AJ, et al. Augmentation of dendritic cells in murine organ donors by Flt3 ligand alters the balance between transplant tolerance and immunity. J Immunol. (1997) 159:5483-91.

8. Li W, Lu L, Wang Z, Wang L, Fung JJ, Thomson AW, et al. Il-12 antagonism enhances apoptotic death of $\mathrm{T}$ cells within hepatic allografts from Flt3 ligand-treated donors and promotes graft acceptance. J Immunol. (2001) 166:5619-28. doi: 10.4049/jimmunol.166.9.5619

9. Yoshida O, Kimura S, Dou L, Matta BM, Yokota S, Ross MA, et al. DAP12 deficiency in liver allografts results in enhanced donor DC migration, augmented effector $\mathrm{T}$ cell responses and abrogation of transplant tolerance. Am J Transplant. (2014) 14:1791-805. doi: 10.1111/ajt.12757

10. Akkaya B, Oya Y, Akkaya M, Al Souz J, Holstein AH, Kamenyeva $\mathrm{O}$, et al. Regulatory $\mathrm{T}$ cells mediate specific suppression by depleting peptide-MHC class II from dendritic cells. Nat Immunol. (2019) 20:21831. doi: 10.1038/s41590-018-0280-2

11. Thomson AW, Humar A, Lakkis FG, Metes DM. Regulatory dendritic cells for promotion of liver transplant operational tolerance: rationale for a clinical trial and accompanying mechanistic studies. Hum Immunol. (2018) 79:314-21. doi: 10.1016/j.humimm.2017.10.017

12. Onoe T, Ohdan H, Tokita D, Shishida M, Tanaka $Y$, Hara H, et al. Liver sinusoidal endothelial cells tolerize $\mathrm{T}$ cells across MHC barriers in mice. $J$ Immunol. (2005) 175:139-46. doi: 10.4049/jimmunol.175.1.139

13. Nishimura H, Nose M, Hiai H, Minato N, Honjo T. Development of lupus-like autoimmune diseases by disruption of the PD-1 gene encoding an ITIM motif-carrying immunoreceptor. Immunity. (1999) 11:14151. doi: 10.1016/S1074-7613(00)80089-8

14. Leach DR, Krummel MF, Allison JP. Enhancement of antitumor immunity by CTLA-4 blockade. Science. (1996) 271:17346. doi: $10.1126 /$ science. 271.5256 .1734

15. Ishida $Y$, Agata $Y$, Shibahara K, Honjo T. Induced expression of PD-1, a novel member of the immunoglobulin gene superfamily, upon programmed cell death. Embo J. (1992) 11:3887-95. doi: 10.1002/j.1460-2075.1992.tb05481.x

16. Tokita D, Shishida M, Ohdan H, Onoe $T$, Hara H, Tanaka $Y$, et al. Liver sinusoidal endothelial cells that endocytose allogeneic cells suppress $\mathrm{T}$ cells with indirect allospecificity. J Immunol. (2006) 177:3615-24. doi: 10.4049/jimmunol.177.6.3615

17. Knolle PA, Limmer A. Neighborhood politics: the immunoregulatory function of organ-resident liver endothelial cells. Trends Immunol. (2001) 22:432-7. doi: 10.1016/S1471-4906(01)01957-3

18. Iwai Y, Terawaki S, Ikegawa M, Okazaki T, Honjo T. PD-1 inhibits antiviral immunity at the effector phase in the liver. J Exp Med. (2003) 198:3950. doi: $10.1084 /$ jem. 20022235

19. Limmer A, Ohl J, Kurts C, Ljunggren HG, Reiss Y, Groettrup M, et al. Efficient presentation of exogenous antigen by liver endothelial cells to CD8+ T cells results in antigen-specific T-cell tolerance. Nat Med. (2000) 6:1348-54. doi: 10.1038/82161
20. Hochst B, Schildberg FA, Bottcher J, Metzger C, Huss S, Turler A, et al. Liver sinusoidal endothelial cells contribute to CD8 T cell tolerance toward circulating carcinoembryonic antigen in mice. Hepatology. (2012) 56:192433. doi: $10.1002 /$ hep. 25844

21. Schurich A, Berg M, Stabenow D, Bottcher J, Kern M, Schild $\mathrm{HJ}$, et al. Dynamic regulation of $\mathrm{CD} 8 \mathrm{~T}$ cell tolerance induction by liver sinusoidal endothelial cells. J Immunol. (2010) 184:410714. doi: 10.4049/jimmunol.0902580

22. Banshodani M, Onoe T, Shishida M, Tahara H, Hashimoto S, Igarashi $Y$, et al. Adoptive transfer of allogeneic liver sinusoidal endothelial cells specifically inhibits T-cell responses to cognate stimuli. Cell Transplant. (2013) 22:1695708. doi: $10.3727 / 096368912$ X657738

23. Igarashi $\mathrm{Y}$, Onoe $\mathrm{T}$, Ohdan $\mathrm{H}$. The role of liver sinusoidal endothelial cells in induction of carbohydrate reactive $\mathrm{B}$ cells tolerance through the programmed death 1 /programmed death ligand 1 pathway. Transplantation. (2015) 99:2325-36. doi: 10.1097/TP.0000000000000831

24. Morita M, Joyce D, Miller C, Fung JJ, Lu L, Qian S. Rejection triggers liver transplant tolerance: involvement of mesenchymemediated immune control mechanisms in mice. Hepatology. (2015) 62:915-31. doi: 10.1002/hep.27909

25. Morita M, Fujino M, Jiang G, Kitazawa Y, Xie L, Azuma M, et al. PD-1/B7-H1 interaction contribute to the spontaneous acceptance of mouse liver allograft. Am J Transplant. (2010) 10:40-6. doi: 10.1111/j.1600-6143.2009.02859.x

26. Hashimoto S, Onoe T, Banshodani M, Taguchi K, Tanaka Y, Ohdan H. Postoperative portal hypertension enhances alloimmune responses after living-donor liver transplantation in patients and in a mouse model. $J$ Immunol. (2019) 203:1392-403. doi: 10.4049/jimmunol.1701147

27. Winau F, Hegasy G, Weiskirchen R, Weber S, Cassan C, Sieling PA, et al. Ito cells are liver-resident antigen-presenting cells for activating $\mathrm{T}$ cell responses. Immunity. (2007) 26:117-29. doi: 10.1016/j.immuni.2006.11.011

28. Yu MC, Chen CH, Liang X, Wang L, Gandhi CR, Fung JJ, et al. Inhibition of T-cell responses by hepatic stellate cells via B7-H1-mediated T-cell apoptosis in mice. Hepatology. (2004) 40:1312-21. doi: 10.1002/hep.20488

29. Charles R, Chou HS, Wang L, Fung JJ, Lu L, Qian S. Human hepatic stellate cells inhibit T-cell response through B7-H1 pathway. Transplantation. (2013) 96:17-24. doi: 10.1097/TP.0b013e318294caae

30. Gu X, Wang Y, Xiang J, Chen Z, Wang L, Lu L, et al. Interferongamma triggers hepatic stellate cell-mediated immune regulation through MEK/ERK signaling pathway. Clin Dev Immunol. (2013) 2013:389807. doi: 10.1155/2013/389807

31. Dunham RM, Thapa M, Velazquez VM, Elrod EJ, Denning TL, Pulendran B, et al. Hepatic stellate cells preferentially induce Foxp3+ regulatory T cells by production of retinoic acid. J Immunol. (2013) 190:200916. doi: 10.4049/jimmunol.1201937

32. Chen $\mathrm{CH}$, Kuo LM, Chang Y, Wu W, Goldbach C, Ross MA, et al. In vivo immune modulatory activity of hepatic stellate cells in mice. Hepatology. (2006) 44:1171-81. doi: 10.1002/hep.21379

33. Kordes C, Sawitza I, Müller-Marbach A, Ale-Agha N, Keitel V, KlonowskiStumpe H, et al. CD133+ hepatic stellate cells are progenitor cells. Biochem Biophys Res Commun. (2007) 352:410-7. doi: 10.1016/j.bbrc.2006.11.029

34. Kordes C, Sawitza I, Götze S, Häussinger D. Hepatic stellate cells support hematopoiesis and are liver-resident mesenchymal stem cells. Cell Physiol Biochem. (2013) 31:290-304. doi: 10.1159/000343368

35. Covas DT, Panepucci RA, Fontes AM, Silva WA Jr., Orellana MD, Peres LC, et al. Multipotent mesenchymal stromal cells obtained from diverse human tissues share functional properties and gene-expression profile with CD146+ perivascular cells and fibroblasts. Exp Hematol. (2008) 36:64254. doi: 10.1016/j.exphem.2007.12.015

36. Aggarwal S, Pittenger MF. Human mesenchymal stem cells modulate allogeneic immune cell responses. Blood. (2005) 105:1815-22. doi: 10.1182/blood-2004-04-1559

37. Krampera M, Glennie S, Dyson J, Scott D, Laylor R, Simpson E, et al. Bone marrow mesenchymal stem cells inhibit the response of naive and memory antigen-specific T cells to their cognate peptide. Blood. (2003) 101:3722-9. doi: 10.1182/blood-2002-07-2104

38. He Y, Zhou S, Liu H, Shen B, Zhao H, Peng K, et al. Indoleamine 2, 3-dioxgenase transfected mesenchymal stem cells induce kidney allograft 
tolerance by increasing the production and function of regulatory $\mathrm{T}$ cells. Transplantation. (2015) 99:1829-38. doi: 10.1097/TP.0000000000000856

39. Detry O, Vandermeulen M, Delbouille MH, Somja J, Bletard N, Briquet A, et al. Infusion of mesenchymal stromal cells after deceased liver transplantation: a phase I-II, open-label, clinical study. J Hepatol. (2017) 67:47-55. doi: 10.1016/j.jhep.2017.03.001

40. Rosser EC, Mauri C. Regulatory B cells: origin, phenotype, and function. Immunity. (2015) 42:607-12. doi: 10.1016/j.immuni.2015.04.005

41. Alhabbab RY, Nova-Lamperti E, Aravena O, Burton HM, Lechler RI, Dorling A, et al. Regulatory B cells: development, phenotypes, functions, and role in transplantation. Immunol Rev. (2019) 292:164-79. doi: 10.1111/imr.12800

42. Peng B, Ming Y, Yang C. Regulatory B cells: the cutting edge of immune tolerance in kidney transplantation. Cell Death Dis. (2018) 9:109. doi: 10.1038/s41419-017-0152-y

43. Khan AR, Hams E, Floudas A, Sparwasser T, Weaver CT, Fallon PG. PD-L1hi B cells are critical regulators of humoral immunity. Nat Commun. (2015) 6:5997. doi: 10.1038/ncomms6997

44. Riccomi A, Palma C. B cells and programmed death-ligand 2 signaling are required for maximal interferon-gamma recall response by splenic $\mathrm{CD} 4^{+}$ memory T cells of mice vaccinated with mycobacterium tuberculosis Ag85B. PLoS ONE. (2015) 10:e0137783. doi: 10.1371/journal.pone.0137783

45. Hirose T, Tanaka Y, Tanaka A, Sakai H, Sasaki Y, Shinohara N, et al. PDL1/PD-L2-expressing B-1 cells inhibit alloreactive T cells in mice. PLoS ONE. (2017) 12:e0178765. doi: 10.1371/journal.pone.0178765

46. Song J, Du G, Chen W, Bao P, Li B, Lu Q, et al. The advantage of sirolimus in amplifying regulatory $\mathrm{B}$ cells and regulatory $\mathrm{T}$ cells in liver transplant patients. Eur J Pharmacol. (2020) 869:172872. doi: 10.1016/j.ejphar.2019.172872

47. Taniguchi M, Harada M, Kojo S, Nakayama T, Wakao $H$. The regulatory role of Valpha14 NKT cells in innate and acquired immune response. Annu Rev Immunol. (2003) 21:483-513. doi: 10.1146/annurev.immunol.21.120601.141057

48. Crosby CM, Kronenberg M. Tissue-specific functions of invariant natural killer $\mathrm{T}$ cells. Nat Rev Immunol. (2018) 18:559-74. doi: 10.1038/s41577-018-0034-2

49. Sonoda KH, Taniguchi M, Stein-Streilein J. Long-term survival of corneal allografts is dependent on intact CD1d-reactive NKT cells. J Immunol. (2002) 168:2028-34. doi: 10.4049/jimmunol.168.4.2028

50. Ikehara Y, Yasunami Y, Kodama S, Maki T, Nakano M, Nakayama T, et al. $\mathrm{CD}^{+}$Valpha14 natural killer T cells are essential for acceptance of rat islet xenografts in mice. J Clin Invest. (2000) 105:1761-7. doi: 10.1172/JCI8922

51. Seino KI, Fukao K, Muramoto K, Yanagisawa K, Takada Y, Kakuta $\mathrm{S}$, et al. Requirement for natural killer $\mathrm{T}$ (NKT) cells in the induction of allograft tolerance. Proc Natl Acad Sci USA. (2001) 98:2577-81. doi: 10.1073/pnas.041608298

52. Morita M, Fujino M, Li XK, Kimura H, Nakayama T, Taniguchi M, et al. Spontaneous tolerance involving natural killer $\mathrm{T}$ cells after hepatic grafting in mice. Transpl Immunol. (2007) 18:142-5. doi: 10.1016/j.trim.2007.05.015

53. Shishida M, Ohdan $\mathrm{H}$, Onoe $\mathrm{T}$, Tanaka $\mathrm{Y}$, Igarashi $\mathrm{Y}$, Banshodani $\mathrm{M}$, et al. Role of invariant natural killer $\mathrm{T}$ cells in liver sinusoidal endothelial cellinduced immunosuppression among $\mathrm{T}$ cells with indirect allospecificity. Transplantation. (2008) 85:1060-4. doi: 10.1097/TP.0b013e31816a3372

54. Reyes J, Zeevi A, Ramos H, Tzakis A, Todo S, Demetris AJ, et al. Frequent achievement of a drug-free state after orthotopic liver transplantation. Transplant Proc. (1993) 25:3315-9.

55. Ramos HC, Reyes J, Abu-Elmagd K, Zeevi A, Reinsmoen N, Tzakis A, et al. Weaning of immunosuppression in long-term liver transplant recipients. Transplantation. (1995) 59:212-7. doi: 10.1097/00007890-199501270-00010

56. Mazariegos GV, Reyes J, Marino IR, Demetris AJ, Flynn B, Irish W, et al. Weaning of immunosuppression in liver transplant recipients. Transplantation. (1997) 63:243-9. doi: 10.1097/00007890-199701270-00012

57. Devlin J, Doherty D, Thomson L, Wong T, Donaldson P, Portmann B, et al. Defining the outcome of immunosuppression withdrawal after liver transplantation. Hepatology. (1998) 27:926-33. doi: 10.1002/hep.510270406

58. Takatsuki $M$, Uemoto $S$, Inomata $\mathrm{Y}$, Egawa $\mathrm{H}$, Kiuchi $\mathrm{T}$, Fujita S, et al. Weaning of immunosuppression in living donor liver transplant recipients. Transplantation. (2001) 72:449-54. doi: 10.1097/00007890-200108150-00016
59. Oike F, Yokoi A, Nishimura E, Ogura Y, Fujimoto Y, Kasahara $\mathrm{M}$, et al. Complete withdrawal of immunosuppression in living donor liver transplantation. Transpl Proc. (2002) 34:1521. doi: 10.1016/S0041-1345(02)02980-9

60. Pons JA, Yelamos J, Ramirez P, Oliver-Bonet M, Sanchez A, Rodriguez-Gago $M$, et al. Endothelial cell chimerism does not influence allograft tolerance in liver transplant patients after withdrawal of immunosuppression. Transplantation. (2003) 75:1045-7. doi: 10.1097/01.TP.0000058472.71775.7D

61. Hurwitz M, Desai DM, Cox KL, Berquist WE, Esquivel CO, Millan MT. Complete immunosuppressive withdrawal as a uniform approach to posttransplant lymphoproliferative disease in pediatric liver transplantation. Pediatr Transplant. (2004) 8:267-72. doi: 10.1111/j.1399-3046.2004.00129.x

62. Eason JD, Cohen AJ, Nair S, Alcantera T, Loss GE. Tolerance: is it worth the risk? Transplantation. (2005) 79:11579. doi: 10.1097/01.TP.0000162084.46555.10

63. Tryphonopoulos P, Tzakis AG, Weppler D, Garcia-Morales R, Kato T, Madariaga JR, et al. The role of donor bone marrow infusions in withdrawal of immunosuppression in adult liver allotransplantation. Am J Transplant. (2005) 5:608-13. doi: 10.1111/j.1600-6143.2004.00743.x

64. Tisone G, Orlando G, Cardillo A, Palmieri G, Manzia TM, Baiocchi L, et al. Complete weaning off immunosuppression in HCV liver transplant recipients is feasible and favourably impacts on the progression of disease recurrence. J Hepatol. (2006) 44:702-9. doi: 10.1016/j.jhep.2005.11.047

65. Martinez-Llordella M, Lozano JJ, Puig-Pey I, Orlando G, Tisone G, Lerut J, et al. Using transcriptional profiling to develop a diagnostic test of operational tolerance in liver transplant recipients. J Clin Invest. (2008) 118:2845-57. doi: 10.1172/JCI35342

66. Manzia TM, Angelico R, Baiocchi L, Toti L, Ciano P, Palmieri G, et al. The tor vergata weaning of immunosuppression protocols in stable hepatitis $\mathrm{C}$ virus liver transplant patients: the 10-year follow-up. Transpl Int. (2013) 26:259-66. doi: 10.1111/tri.12023

67. Assy N, Adams PC, Myers P, Simon V, Ghent CN. A randomised controlled trial of total immunosuppression withdrawal in stable liver transplant recipients. Gut. (2007) 56:304-6. doi: 10.1136/gut.2006.107862

68. Lee JH, Lee SK, Lee HJ, Seo JM, Joh JW, Kim SJ, et al. Withdrawal of immunosuppression in pediatric liver transplant recipients in Korea. Yonsei Med J. (2009) 50:784-8. doi: 10.3349/ymj.2009.50.6.784

69. Feng S, Ekong UD, Lobritto SJ, Demetris AJ, Roberts JP, Rosenthal $\mathrm{P}$, et al. Complete immunosuppression withdrawal and subsequent allograft function among pediatric recipients of parental living donor liver transplants. JAMA. (2012) 307:283-93. doi: 10.1001/jama. 2011.2014

70. de la Garza RG, Sarobe P, Merino J, Lasarte JJ, D’Avola D, Belsue V, et al. Trial of complete weaning from immunosuppression for liver transplant recipients: factors predictive of tolerance. Liver Transpl. (2013) 19:93744. doi: 10.1002/lt.23686

71. Benitez C, Londono MC, Miquel R, Manzia TM, Abraldes JG, Lozano $\mathrm{JJ}$, et al. Prospective multicenter clinical trial of immunosuppressive drug withdrawal in stable adult liver transplant recipients. Hepatology. (2013) 58:1824-35. doi: 10.1002/hep.26426

72. Bohne F, Londono MC, Benitez C, Miquel R, Martinez-Llordella M, Russo $\mathrm{C}$, et al. HCV-induced immune responses influence the development of operational tolerance after liver transplantation in humans. Sci Transl Med. (2014) 6:242ra81. doi: 10.1126/scitranslmed.3008793

73. Lin NC, Wang HK, Yeh YC, Liu CP, Loong CC, Tsai HL, et al. Minimization or withdrawal of immunosuppressants in pediatric liver transplant recipients. J Pediatr Surg. (2015) 50:2128-33. doi: 10.1016/j.jpedsurg.2015.08.043

74. Levitsky J, Burrell BE, Kanaparthi S, Turka LA, Kurian S, Sanchez-Fueyo A, et al. Immunosuppression withdrawal in liver transplant recipients on sirolimus. Hepatology. (2019) doi: 10.1002/hep.31036. [Epub ahead of print].

75. Shaked A, DesMarais MR, Kopetskie H, Feng S, Punch JD, Levitsky $\mathrm{J}$, et al. Outcomes of immunosuppression minimization and withdrawal early after liver transplantation. Am J Transplant. (2019) 19:1397409. doi: 10.1111/ajt.15205

76. Billingham RE, Brent L, Medawar PB. Actively acquired tolerance of foreign cells. Nature. (1953) 172:603-6. doi: 10.1038/172603a0 
77. Slavin S, Strober S, Fuks Z, Kaplan HS. Induction of specific tissue transplantation tolerance using fractionated total lymphoid irradiation in adult mice: long-term survival of allogeneic bone marrow and skin grafts. J Exp Med. (1977) 146:34-48. doi: 10.1084/jem.146.1.34

78. Ildstad ST, Sachs DH. Reconstitution with syngeneic plus allogeneic or xenogeneic bone marrow leads to specific acceptance of allografts or xenografts. Nature. (1984) 307:168-70. doi: 10.1038/307168a0

79. Kaneku H, O’Leary JG, Banuelos N, Jennings LW, Susskind BM, Klintmalm GB, et al. De novo donor-specific HLA antibodies decrease patient and graft survival in liver transplant recipients. Am J Transplant. (2013) 13:15418. doi: 10.1111/ajt.12212

80. Jucaud V, Shaked A, DesMarais M, Sayre P, Feng S, Levitsky J, et al. Prevalence and Impact of de novo donor-specific antibodies during a multicenter immunosuppression withdrawal trial in adult liver transplant recipients. Hepatology. (2019) 69:1273-86. doi: 10.1002/hep.30281

81. Schroeder HW Jr., Cavacini L. Structure and function of immunoglobulins. J Allergy Clin Immunol. (2010) 125(Suppl. 2):S41-52. doi: 10.1016/j.jaci.2009.09.046

82. O’Leary JG, Kaneku H, Banuelos N, Jennings LW, Klintmalm GB, Terasaki PI. Impact of IgG3 subclass and C1q-fixing donor-specific HLA alloantibodies on rejection and survival in liver transplantation. Am J Transplant. (2015) 15:1003-13. doi: 10.1111/ajt.13153

83. Jackson AM, Kanaparthi S, Burrell BE, Lucas DP, Vega RM, Demetris AJ, et al. IgG4 donor-specific HLA antibody profile is associated with subclinical rejection in stable pediatric liver recipients. Am J Transplant. (2020) 20:51324. doi: 10.1111/ajt.15621

84. Feng S, Bucuvalas JC, Demetris AJ, Burrell BE, Spain KM, Kanaparthi S, et al. Evidence of chronic allograft injury in liver biopsies from long-term pediatric recipients of liver transplants. Gastroenterology. (2018) 155:183851.e7. doi: 10.1053/j.gastro.2018.08.023

85. Duquesnoy RJ. HLA epitopes and tolerance induction protocols. Am J Transplant. (2014) 14:2667. doi: 10.1111/ajt.12960

86. Meszaros M, Dubois V, Niemann M, Ursic-Bedoya J, Faure S, Guillaud O, et al. Class II human leukocyte antigen epitope mismatch predicts de novo donor-specific antibody formation after liver transplantation. Liver Transpl. (2019) 25:184-5. doi: 10.1002/lt.25357

87. Kubal CA, Mangus R, Ekser B, Mihaylov P, Ceballos B, Higgins N, et al. Class II human leukocyte antigen epitope mismatch predicts de novo donorspecific antibody formation after liver transplantation. Liver Transpl. (2018) 24:1101-8. doi: 10.1002/lt.25286

88. Bohne F, Martinez-Llordella M, Lozano JJ, Miquel R, Benitez C, Londono $\mathrm{MC}$, et al. Intra-graft expression of genes involved in iron homeostasis predicts the development of operational tolerance in human liver transplantation. J Clin Invest. (2012) 122:368-82. doi: 10.1172/JCI59411

89. Taubert R, Danger R, Londono MC, Christakoudi S, Martinez-Picola M, Rimola A, et al. Hepatic infiltrates in operational tolerant patients after liver transplantation show enrichment of regulatory $\mathrm{T}$ cells before proinflammatory genes are downregulated. Am J Transplant. (2016) 16:1285-93. doi: 10.1111/ajt.13617

90. Mazariegos GV, Zahorchak AF, Reyes J, Ostrowski L, Flynn B, Zeevi A, et al. Dendritic cell subset ratio in peripheral blood correlates with successful withdrawal of immunosuppression in liver transplant patients. Am J Transplant. (2003) 3:689-96. doi: 10.1034/j.1600-6143.2003.00109.x

91. Li L, Wozniak LJ, Rodder S, Heish S, Talisetti A, Wang Q, et al. A common peripheral blood gene set for diagnosis of operational tolerance in pediatric and adult liver transplantation. Am J Transplant. (2012) 12:121828. doi: 10.1111/j.1600-6143.2011.03928.x

92. Jhun J, Lee SH, Lee SK, Kim HY, Jung ES, Kim DG, et al. Serial monitoring of immune markers being represented regulatory $\mathrm{T}$ Cell/T helper 17 cell ratio: indicating tolerance for tapering immunosuppression after liver transplantation. Front Immunol. (2018) 9:352. doi: 10.3389/fimmu.2018.00352

93. Segall M, Noreen H, Edwins L, Haake R, Shu XO, Kersey J. Lack of correlation of MLC reactivity with acute graft-versus-host disease and mortality in unrelated donor bone marrow transplantation. Hum Immunol. (1996) 49:49-55. doi: 10.1016/0198-8859(96)00055-9

94. Thomson AW, Mazariegos GV, Reyes J, Donnenberg VS, Donnenberg $\mathrm{AD}$, Bentlejewski $\mathrm{C}$, et al. Monitoring the patient off immunosuppression.
Conceptual framework for a proposed tolerance assay study in liver transplant recipients. Transplantation. (2001) 72(Suppl. 8):S13-22.

95. Truong DQ, Cornet A, Wieers G, Robert A, Reding R, Latinne D. Pre- and post-transplant monitoring of granzyme B enzyme-linked immunosorbent spot assay in pediatric liver recipients. Transpl Immunol. (2008) 19:2159. doi: 10.1016/j.trim.2008.06.001

96. Nasr M, Sigdel T, Sarwal M. Advances in diagnostics for transplant rejection. Expert Rev Mol Diagn. (2016) 16:112132. doi: 10.1080/14737159.2016.1239530

97. Wells AD, Gudmundsdottir H, Turka LA. Following the fate of individual T cells throughout activation and clonal expansion. Signals from $\mathrm{T}$ cell receptor and CD28 differentially regulate the induction and duration of a proliferative response. J Clin Invest. (1997) 100:3173-83. doi: 10.1172/JCI119873

98. Tanaka Y, Tashiro H, Onoe T, Ide K, Ishiyama K, Ohdan H. Optimization of immunosuppressive therapy based on a multiparametric mixed lymphocyte reaction assay reduces infectious complications and mortality in living donor liver transplant recipients. Transplant Proc. (2012) 44:5559. doi: 10.1016/j.transproceed.2012.01.038

99. Tanaka Y, Ohdan H, Onoe T, Asahara T. Multiparameter flow cytometric approach for simultaneous evaluation of proliferation and cytokinesecreting activity in T cells responding to allo-stimulation. Immunol Invest. (2004) 33:309-24. doi: 10.1081/IMM-120038079

100. Tanaka $\mathrm{Y}$, Ohdan $\mathrm{H}$, Onoe $\mathrm{T}$, Mitsuta $\mathrm{H}$, Tashiro $\mathrm{H}$, Itamoto $\mathrm{T}$ et al. Low incidence of acute rejection after living-donor liver transplantation: immunologic analyses by mixed lymphocyte reaction using a carboxyfluorescein diacetate succinimidyl ester labeling technique. Transplantation. (2005) 79:1262-7. doi: 10.1097/01.TP.0000161667.99145.20

101. Sakai H, Ishiyama K, Tanaka Y, Ide K, Ohira M, Tahara H, et al. Potential benefit of mixed lymphocyte reaction assay-based immune monitoring after living donor liver transplantation for recipients with autoimmune hepatitis. Transplant Proc. (2014) 46:785-9. doi: 10.1016/j.transproceed.2013.11.123

102. Takeda K, Sawada Y, Kumamoto T, Matsuyama R, Tanaka Y, Ohdan $\mathrm{H}$, et al. Successful multidisciplinary treatment of refractory cytomegalovirus infection after living donor liver transplantation using mixed lymphocyte reactions: report of a case. Clin J Gastroenterol. (2016) 9:38-42. doi: 10.1007/s12328-016-0627-x

103. Tahara H, Tanaka $Y$, Ishiyama K, Ide K, Shishida M, Irei $T$, et al. Successful hepatitis B vaccination in liver transplant recipients with donor-specific hyporesponsiveness. Transpl Int. (2009) 22:805-13. doi: 10.1111/j.1432-2277.2009.00864.x

104. Ide K, Tanaka Y, Onoe T, Banshodani M, Tazawa H, Igarashi Y, et al. Evidence for the immunosuppressive potential of calcineurin inhibitorsparing regimens in liver transplant recipients with impaired renal function. J Transplant. (2011) 2011:483728. doi: 10.1155/2011/483728

105. Morris H, DeWolf S, Robins H, Sprangers B, LoCascio SA, Shonts $\mathrm{BA}$, et al. Tracking donor-reactive $\mathrm{T}$ cells: evidence for clonal deletion in tolerant kidney transplant patients. Sci Transl Med. (2015) 7:272ra10. doi: 10.1126/scitranslmed.3010760

106. DeWolf S, Sykes M. Alloimmune T cells in transplantation. J Clin Invest. (2017) 127:2473-81. doi: 10.1172/JCI90595

107. Savage TM, Shonts BA, Lau S, Obradovic A, Robins H, Shaked A, et al. Deletion of donor-reactive $\mathrm{T}$ cell clones after human liver transplant. Am J Transplant. (2020) 20:538-45. doi: 10.1111/ajt.15592

108. Chattopadhyay PK, Yu J, Roederer M. A live-cell assay to detect antigenspecific CD4+ T cells with diverse cytokine profiles. Nat Med. (2005) 11:1113-7. doi: 10.1038/nm1293

109. Frentsch M, Arbach O, Kirchhoff D, Moewes B, Worm M, Rothe M, et al. Direct access to CD4+ $\mathrm{T}$ cells specific for defined antigens according to CD154 expression. Nat Med. (2005) 11:1118-24. doi: 10.1038/nm1292

110. Ashokkumar C, Talukdar A, Sun Q, Higgs BW, Janosky J, Wilson $\mathrm{P}$, et al. Allospecific CD154+ $\mathrm{T}$ cells associate with rejection risk after pediatric liver transplantation. Am J Transplant. (2009) 9:17991. doi: 10.1111/j.1600-6143.2008.02459.x

111. Wolfl M, Kuball J, Ho WY, Nguyen H, Manley TJ, Bleakley M, et al. Activation-induced expression of CD137 permits detection, isolation, and expansion of the full repertoire of $\mathrm{CD} 8+\mathrm{T}$ cells responding to antigen without requiring knowledge of epitope specificities. Blood. (2007) 110:20110. doi: 10.1182/blood-2006-11-056168 
112. Schoenbrunn A, Frentsch M, Kohler S, Keye J, Dooms H, Moewes B, et al. A converse 4-1BB and CD40 ligand expression pattern delineates activated regulatory $\mathrm{T}$ cells (Treg) and conventional $\mathrm{T}$ cells enabling direct isolation of alloantigen-reactive natural Foxp3 + treg. J Immunol. (2012) 189:598594. doi: 10.4049/jimmunol.1201090

113. Nowak A, Lock D, Bacher P, Hohnstein T, Vogt K, Gottfreund $\mathrm{J}$, et al. CD137+CD154- expression as a regulatory $\mathrm{T}$ cell (Treg)specific activation signature for identification and sorting of stable human tregs from in vitro expansion cultures. Front Immunol. (2018) 9:199. doi: 10.3389/fimmu.2018.00199

114. Sakaguchi S, Fukuma K, Kuribayashi K, Masuda T. Organ-specific autoimmune diseases induced in mice by elimination of $\mathrm{T}$ cell subset. I. Evidence for the active participation of T cells in natural self-tolerance; deficit of a $\mathrm{T}$ cell subset as a possible cause of autoimmune disease. J Exp Med. (1985) 161:72-87. doi: 10.1084/jem.161.1.72

115. Sakaguchi S, Sakaguchi N, Asano M, Itoh M, Toda M. Immunologic selftolerance maintained by activated $\mathrm{T}$ cells expressing IL-2 receptor alphachains (CD25). Breakdown of a single mechanism of self-tolerance causes various autoimmune diseases. J Immunol. (1995) 155:1151-64.

116. Hori S, Nomura $\mathrm{T}$, Sakaguchi S. Control of regulatory $\mathrm{T}$ cell development by the transcription factor Foxp3. Science. (2003) 299:1057-61. doi: 10.1126/science.1079490

117. Brunstein CG, Miller JS, Cao Q, McKenna DH, Hippen KL, Curtsinger J, et al. Infusion of ex vivo expanded T regulatory cells in adults transplanted with umbilical cord blood: safety profile and detection kinetics. Blood. (2011) 117:1061-70. doi: 10.1182/blood-2010-07-293795

118. Di Ianni M, Falzetti F, Carotti A, Terenzi A, Castellino F, Bonifacio E, et al. Tregs prevent GVHD and promote immune reconstitution in HLA-haploidentical transplantation. Blood. (2011) 117:3921-8. doi: 10.1182/blood-2010-10-311894

119. Edinger M, Hoffmann P. Regulatory $\mathrm{T}$ cells in stem cell transplantation: strategies and first clinical experiences. Curr Opin Immunol. (2011) 23:67984. doi: 10.1016/j.coi.2011.06.006

120. Todo S, Yamashita K, Goto R, Zaitsu M, Nagatsu A, Oura T, et al. A pilot study of operational tolerance with a regulatory T-cell-based cell therapy in living donor liver transplantation. Hepatology. (2016) 64:63243. doi: 10.1002/hep.28459

121. Todo S, Yamashita K. Anti-donor regulatory $\mathrm{T}$ cell therapy in liver transplantation. Hum Immunol. (2018) 79:28893. doi: 10.1016/j.humimm.2017.12.010

122. Safinia N, Grageda N, Scotta C, Thirkell S, Fry LJ, Vaikunthanathan $\mathrm{T}$, et al. Cell therapy in organ transplantation: our experience on the clinical translation of regulatory $\mathrm{T}$ cells. Front Immunol. (2018) 9:354. doi: 10.3389/fimmu.2018.00354

123. Tang Q, Vincenti F. Transplant trials with tregs: perils and promises. J Clin Invest. (2017) 127:2505-12. doi: 10.1172/JCI90598

124. Buchholz BM, Ferguson JW, Schnitzbauer AA, Nightingale P, Schlitt HJ, Geissler EK, et al. Randomized sirolimus-based early calcineurin inhibitor reduction in liver transplantation: impact on renal function. Transplantation. (2019) 104:1003-18. doi: 10.1097/TP.0000000000002980

125. Saliba F, Duvoux C, Gugenheim J, Kamar N, Dharancy S, Salame E, et al. Efficacy and safety of everolimus and mycophenolic acid with early tacrolimus withdrawal after liver transplantation: a multicenter randomized trial. Am J Transplant. (2017) 17:1843-52. doi: 10.1111/ajt.14212

126. Glover TE, Watson CJ, Gibbs P, Bradley JA, Ntzani EE, Kosmoliaptsis V. Conversion from calcineurin to mammalian target of rapamycin inhibitors in liver transplantation: a meta-analysis of randomized controlled trials. Transplantation. (2016) 100:621-9. doi: 10.1097/TP.0000000000 001006

127. Wu YM, Joseph B, Gupta S. Immunosuppression using the mTOR inhibition mechanism affects replacement of rat liver with transplanted cells. Hepatology. (2006) 44:410-9. doi: 10.1002/hep.21277

128. Semela D, Piguet AC, Kolev M, Schmitter K, Hlushchuk R, Djonov V, et al. Vascular remodeling and antitumoral effects of mTOR inhibition in a rat model of hepatocellular carcinoma. J Hepatol. (2007) 46:8408. doi: 10.1016/j.jhep.2006.11.021
129. Villanueva A, Chiang DY, Newell P, Peix J, Thung S, Alsinet C, et al. Pivotal role of mTOR signaling in hepatocellular carcinoma. Gastroenterology. (2008) 135:1972-198411. doi: 10.1053/j.gastro.2008.08.008

130. Grigg SE, Sarri GL, Gow PJ, Yeomans ND. Systematic review with metaanalysis: sirolimus- or everolimus-based immunosuppression following liver transplantation for hepatocellular carcinoma. Aliment Pharmacol Ther. (2019) 49:1260-73. doi: 10.1111/apt.15253

131. Tanimine N, Turka LA, Priyadharshini B. Navigating $\mathrm{T}$ cell immunometabolism in transplantation. Transplantation. (2017) 102:230-9. doi: 10.1097/TP.0000000000001951

132. Yang JY, Sarwal MM. Transplant genetics and genomics. Nat Rev Genet. (2017) 18:309-26. doi: 10.1038/nrg.2017.12

133. Brugiere O, Thabut G, Krawice-Radanne I, Rizzo R, Dauriat G, Danel C, et al. Role of HLA-G as a predictive marker of low risk of chronic rejection in lung transplant recipients: a clinical prospective study. Am J Transplant. (2015) 15:461-71. doi: 10.1111/ajt.12977

134. Qiu J, Terasaki PI, Miller J, Mizutani K, Cai J, Carosella ED. Soluble HLA$\mathrm{G}$ expression and renal graft acceptance. Am J Transplant. (2006) 6:21526. doi: 10.1111/j.1600-6143.2006.01417.x

135. Lila N, Carpentier A, Amrein C, Khalil-Daher I, Dausset J, Carosella ED. Implication of HLA-G molecule in heart-graft acceptance. Lancet. (2000) 355:2138. doi: 10.1016/S0140-6736(00)02386-2

136. Naji A, Le Rond S, Durrbach A, Krawice-Radanne I, Creput C, Daouya $\mathrm{M}$, et al. CD3+CD4low and CD3+CD8low are induced by HLA-G: novel human peripheral blood suppressor T-cell subsets involved in transplant acceptance. Blood. (2007) 110:3936-48. doi: 10.1182/blood-2007-04-083139

137. Thude H, Janssen M, Sterneck M, Nashan B, Koch M. 14-bp ins/del polymorphism and $+3142 \mathrm{C}>\mathrm{G}$ SNP of the HLA-G gene have a significant impact on acute rejection after liver transplantation. Hum Immunol. (2016) 77:1159-65. doi: 10.1016/j.humimm.2016.09.009

138. Zhang T, Liu Y, Zeng R, Ling Q, Wen P, Fan J, et al. Association of donor small ubiquitin-like modifier 4 rs237025 genetic variant with tacrolimus elimination in the early period after liver transplantation. Liver Int. (2018) 38:724-32. doi: 10.1111/liv.13597

139. Verma S, Tanaka Y, Shimizu S, Tanimine N, Ohdan H. Significant association between FOXP3 gene polymorphism and steroid-resistant acute rejection in living donor liver transplantation. Hepatol Commun. (2017) 1:40620. doi: 10.1002/hep4.1052

140. Millan O, Ruiz P, Orts L, Ferre P, Crespo G, Santana M, et al. Monitoring of miR-181a-5p and miR-155-5p plasmatic expression as prognostic biomarkers for acute and subclinical rejection in de novo adult liver transplant recipients. Front Immunol. (2019) 10:873. doi: 10.3389/fimmu.2019.00873

141. Revilla-Nuin B, de Bejar A, Martinez-Alarcon L, Herrero JI, MartinezCaceres CM, Ramirez P, et al. Differential profile of activated regulatory T cell subsets and microRNAs in tolerant liver transplant recipients. Liver Transpl. (2017) 23:933-45. doi: 10.1002/lt.24691

142. Vitalone MJ, Wei L, Fujiki M, Lau AH, Littau E, Esquivel C, et al. Liver microRNA profile of induced allograft tolerance. Transplantation. (2016) 100:781-90. doi: 10.1097/TP.0000000000001105

143. Morita M, Chen J, Fujino M, Kitazawa Y, Sugioka A, Zhong L, et al. Identification of microRNAs involved in acute rejection and spontaneous tolerance in murine hepatic allografts. Sci Rep. (2014) 4:6649. doi: $10.1038 /$ srep06649

Conflict of Interest: The authors declare that the research was conducted in the absence of any commercial or financial relationships that could be construed as a potential conflict of interest.

Copyright (C) 2020 Tanimine, Ohira, Tahara, Ide, Tanaka, Onoe and Ohdan. This is an open-access article distributed under the terms of the Creative Commons Attribution License (CC BY). The use, distribution or reproduction in other forums is permitted, provided the original author(s) and the copyright owner(s) are credited and that the original publication in this journal is cited, in accordance with accepted academic practice. No use, distribution or reproduction is permitted which does not comply with these terms. 